\title{
Soil fungal diversity and functionality are driven by plant species used in phytoremediation
}

Gil-Martínez, Marta ${ }^{a^{*}}$; López-García, Álvaro ${ }^{\text {b,d; }}$ Domínguez, María T.; Kjøller, Rasmus $^{\mathrm{d}}$; Navarro-Fernández, Carmen M. ${ }^{\mathrm{a}}$; Rosendahl, Søren ${ }^{\mathrm{d}}$; Marañón, Teodoro ${ }^{\mathrm{a}}$

${ }^{a}$ Department for Protection of the Soil, Plant and Water System, Institute of Natural Resources and Agrobiology of Seville, Spanish National Research Council, Avenida Reina Mercedes, 10, 41014, Seville, Spain.

${ }^{\mathrm{b}}$ Department of Animal Biology, Plant Biology and Ecology, Universidad de Jaén, Campus Las Lagunillas, s/n, 23071, Jaén, Spain.

c Área de Edafología y Química Agrícola, Departamento de Cristalografía, Mineralogía y Química Agrícola, Universidad de Sevilla, Calle Profesor García González, s/n, 41012 Seville, Spain.

${ }^{d}$ Department of Biology, University of Copenhagen, Universitetsparken, 15, 2100, Copenhagen, Denmark.

* Corresponding author

Correspondence email: marta.gil@irnas.csic.es

Correspondence postal address: Avenida Reina Mercedes no 10, 41012, Sevilla, Spain 


\section{ABSTRACT}

Soil biodiversity loss due to pollution may affect ecosystem services negatively. This environmental problem may be solved by phytoremediation, which is an effective strategy to manage and remediate contaminated areas. During this remediation process, the establishment of plant communities may improve soil fungal community structure and, in particular, may favour mycorrhizal symbiotic associations. As a consequence, afforestation of degraded lands will have different outcomes on fungal diversity and functionality, which will depend on the selected tree and shrub species.

We analysed soil fungal diversity and functional guilds by high-throughput sequencing of environmental DNA in a trace element contaminated area, part of a large scale phytoremediation project running for 20 years. We selected five habitats for comparison purposes: three under the canopy of selected tree species (wild olive, white poplar and stone pine), adjacent treeless areas (grassland) and non-remediated areas (bare soil).

Soil fungal diversity and richness seemed to be enhanced by phytoremediation. White poplar soil had the highest diversity and richness compared to wild olive and stone pine. Fungal communities were especially different between stone pine, with soils rich in organic $\mathrm{C}$ and high $\mathrm{C}: \mathrm{N}$ ratio, and grassland soils.

We identified 9,428 fungal OTUs from which 1,283 were assigned to a unique functional guild; the most abundant belonging to saprotrophic, plant pathogenic and ectomycorrhizal functional guilds. Ectomycorrhizal fungi were more abundant in soils under ectomycorrhizal host trees. Saprotrophs were abundant in grassland and wild olive soils, while plant pathogens were abundant in non-remediated soils. 
The remediation of soils (clean-up and amendment addition) allowed the natural establishment of grassland habitats throughout the study area, increasing fungal diversity, richness, taxonomy and functionality, when compared to non-remediated soils. Tree afforestation allowed the establishment of a forest type community bringing a further recruitment of fungal taxa, mainly the ectomycorrhizal fungal guild. Afforestation with different tree species showed species-specific effects on soil $\mathrm{N}$, organic $\mathrm{C}, \mathrm{Ca}$ and $\mathrm{C}: \mathrm{N}$ ratio which led to increased spatial heterogeneity in areas with potential to recruit a wider diversity of fungi.

\section{KEYWORDS}

Contamination; Fungi; Heavy metal; Mycorrhizal fungi; Saprotrophic fungi; Trace elements

\section{INTRODUCTION}

Fungi are major components of the soil microbiota, harbouring a wide diversity of lifehistory strategies which deliver diverse ecological functions (Sun et al., 2017). Among their key functions, fungi are decomposers (saprotrophs), contributing to nutrient cycling; pathogens, regulating plant community composition; and mutualists (e.g. mycorrhizal), providing multiple services to plants (Nilsson et al., 2019; Tedersoo et al., 2014b; van der Heijden et al., 2008). However, there is evidence that soil fungal biodiversity declines as part of a global soil biodiversity loss due to human activities, causing negative effects on ecosystem services (Geisen et al., 2019; Veresoglou et al., 2015). Soil pollution is one of the main drivers of biodiversity loss and ecosystem change (Rodríguez-Eugenio et al., 2018; Gardi et al., 2013). Phytoremediation aims to recover contaminated land by using 
plants and their associated microorganisms to remove, detoxify and/or retain contaminants (Bolan et al., 2011). Phytoremediation has been proven as an effective strategy to manage trace element contaminated areas (Madejón et al., 2018a; Wang et al., 2017). In general, restoration progress after ecosystem disturbances can be evaluated by measuring recovery of soil microbial diversity and activity (Bünemann et al., 2018; Banning et al., 2011). In the case of soils contaminated by trace elements, establishment of plant communities leads to changes in fungal community structure and, in particular, to the establishment of symbiotic mycorrhizal associations (Gil-Martínez et al., 2018; Op De Beeck et al., 2015; van der Heijden et al., 1998). Mycorrhizal symbiosis plays a critical role in water and nutrient uptake by host plants and enhances plant tolerance to trace elements in these harsh environments (Cabral et al., 2015; Smith and Read, 2008).

As plants are colonizing degraded areas, and organic matter and nutrients accumulate, the fungal community structure becomes more deterministic, and can be explained by environmental factors (Dini-Andreote et al., 2015). Development of fungal communities after afforestation of degraded lands may have different outcomes depending on the plant species used. Indeed, in mixed forests, the establishment of different tree species increases fungal diversity as different tree species are associated with a characteristic fungal community (Unterseher et al., 2008). Trees may affect soil fungal communities to a wider extent than herbaceous species as they produce higher litter quantities and their roots are wider and deeper, creating heterogeneous environments for understory vegetation and fauna (Sun et al., 2016). Indeed, plant lifeform and mycorrhizal type drive fungal communities to a wider extent than plant species identity (Tedersoo et al., 2014b). Differences in the predominant functional guilds were observed between forested and treeless ecosystems, being ectomycorrhizae-dominated communities favoured in forested soils (Sun et al., 2016; Tedersoo et al., 2012, 2014b). Tree composition has also been 
found to enhance specific fungal guilds, such as parasitic and mycorrhizal (Peay et al., 2013).

At the same time, abiotic factors also have direct and indirect (through affecting plant performance) effects on soil microbial communities (Gil-Martínez et al., 2018). Among these factors, $\mathrm{pH}$ and nutrient content $(\mathrm{N}, \mathrm{P}, \mathrm{Ca}$ and $\mathrm{C}: \mathrm{N}$ ratio) of soils have been repeatedly considered as principal regulators of soil fungal communities (NarendrulaKotha and Nkongolo, 2017; Sun et al., 2016; Tedersoo et al., 2014b). However, in disturbed areas, soil fungal communities have shown a higher correlation with plant community composition than with soil abiotic properties (Mueller et al., 2014).

Studying the relative contribution of plant identity and soil properties in mining-affected soils represents an opportunity to understand how microbial communities develop in soils dramatically degraded. Indeed, mining related activities have produced land disturbances around the world, generating severely contaminated areas, that have motivated some large scale phytoremediation projects (Wang et al., 2017; Pulford and Watson, 2003). However, studies addressing how the interactions between plant species identity and initial soil factors determine soil biological communities are scarce (van der Linde et al., 2018; de Vries et al., 2012; Berg and Smalla, 2009) and hence the ecological basis for the design of successful phytoremediation strategies is still incomplete. More knowledge is needed to understand the importance of the plant species used in phytoremediation activities and the necessary conditions for plant establishment.

In this study, we analysed soil fungal diversity and functional guilds in a trace element contaminated area, afforested 20 years before this analysis, as part of a large-scale phytoremediation project. We selected patches with different vegetation covers (soil covered by trees species, herbaceous plants or bare soils), corresponding to different degrees of intervention during the implementation of the project, in order to understand 
how vegetation affects composition and diversity of soil fungal communities. Bare soils correspond to areas where soil contaminants were not removed or areas where the soil amendments were not applied and no vegetation was able to establish; grassland areas were the result of actively cleaning and amending soils, but these soils were not afforested and were naturally colonized by herbaceous species; soils underneath trees were actively cleaned, amended and afforested. We hypothesized that 20 years after the restoration started, (i) soil fungal diversity would increase with the degree of intervention, (ii) composition of soil fungal communities would be affected by both vegetation cover (in particular by tree identity) and soil properties and (iii) fungal functional diversity, with special focus on mycorrhizal communities, would be mostly influenced by tree identity. Elucidating these points would help to better evaluate the success of managing the restoration of contaminated soils.

\section{MATERIALS AND METHODS}

\subsection{Study area and tree species}

The study was conducted in the Guadiamar Green Corridor, which is located in SW Spain and measures $60 \mathrm{~km}$ long and up to $2 \mathrm{~km}$ wide along the Guadiamar River (Fig. S1; A). This area was affected by a mine spill in 1998 which contaminated the Guadiamar River Valley with acidic waters and sludge from the pyrite mine tailings (Cabrera et al., 1999). The soils were severely contaminated by trace elements and a large-scale phytoremediation plan was carried out. The plan included removal of deposited sludge and contaminated topsoil, followed by addition of organic matter and calcium amendments to increase $\mathrm{pH}$, and by the afforestation of the affected soils with native tree and shrub species (Madejón et al., 2018a; Domínguez et al., 2008). Once remediated, 
agriculture and husbandry were abandoned, and the area was legally declared as Protected Landscape (Madejón et al., 2018b; Arenas et al., 2003). The clean-up was not homogenous and some areas were still degraded and contaminated to such an extent that vegetation was not able to re-establish (García-Carmona et al., 2019). These soils contained remnants of sludge that led to soil acidification and high availability of trace elements (Domínguez et al., 2016). For research purposes, some control areas were maintained where sludge was not removed and soils were not amended.

We repeated the sampling design at two sites (of contrasting lithology and geomorphology). The North site $\left(37^{\circ} 23^{\prime} 08.85^{\prime \prime} \mathrm{N}, 6^{\circ} 13^{\prime} 41.81^{\prime \prime} \mathrm{W}\right)$ is located $15 \mathrm{~km}$ away from the mine tailings spill point and the soil type is Typic Xerofluvent (Soil Survey Staff, 2014) non-calcareous, with a sandy loam texture (Cabrera et al., 1999) (Fig. S1; B). The South site $\left(37^{\circ} 14^{\prime} 35.90^{\prime \prime} \mathrm{N}, 6^{\circ} 15^{\prime} 49.74^{\prime \prime} \mathrm{W}\right)$ is located $30 \mathrm{~km}$ away from the mine tailings spill and the soil type is also Typic Xerofluvent, but calcareous and with a loam texture (Cabrera et al., 1999) (Fig. S1; C). Climatic conditions are Mediterranean with mild rainy winters and warm dry summers. Average annual temperature is $18.6^{\circ} \mathrm{C}$ and annual average rainfall is $576 \mathrm{~mm}$.

The afforestation program implemented in 1999-2000 included planting saplings of more than 40 woody species at a density of 700-900 plants ha ${ }^{-1}$, in a mixed design to simulate natural forest conditions. Planted saplings had to resist summer drought, high irradiance, altered soil structure, residual contamination and competition from herbaceous plants, which resulted in a high mortality of some species over the first years after planting (Domínguez et al., 2010). Eighteen years after afforestation, we selected to study three tree species with different life-history strategies that were well established in both sites:

- Wild olive (Olea europaea subsp. europaea var. sylvestris (Mill.) Lehr) is a long-lived, evergreen tree which has been cultivated and extensively planted in the Mediterranean 
Basin with a complex genetic of wild and feral forms (Lumaret et al., 2004). Wild olive roots form symbiotic associations with arbuscular mycorrhizal (AM) fungi (Maremmani et al., 2003).

- White poplar (Populus alba L.) is a fast growing deciduous tree, abundant in the riparian forests of the Mediterranean Basin, central Europe and western Asia (Palancean et al., 2018). As most members of the Salicaceae family they accumulate metals in their leaves, and in the study site they have been used as bioindicators for the availability of $\mathrm{Cd}$ and $\mathrm{Zn}$ in the soil (Madejón et al., 2004). White poplar forms associations with both ectomycorrhizal (ECM) and AM fungi (Maremmani et al., 2003).

- Stone or umbrella pine (Pinus pinea L.) is a coniferous tree widely distributed around the Mediterranean Basin. It is economically important as a source of wood and edible seeds, and it has been extensively planted since historical times (Fady et al., 2008). Its successful colonization and persistence in infertile and sandy soils depends mainly on their symbiotic association with ECM fungi compared to AM fungi (Rincón et al., 1999).

There were size differences among tree species. Wild olive tree specimens were smallest in height and crown projection, and their growth was more reduced at the North site (Table S1). White poplar was the biggest tree species at the North site and stone pine at the South site.

- Herbaceous communities colonized the remediated area, and their species composition was heterogeneous and diverse. These grasslands formed a matrix where tree and shrub saplings were originally afforested. Their main management has been slashing and horsegrazing to reduce fuel amount and fire risk (Madejón et al., 2009). Some species dominant in the North site were: Piptatherum miliaceum (L.) Coss., Agrostis pourretii Willd., Bromus lanceolatus Roth, Hordeum murinum L., Silybum marianum (L.) Gaertn. and 
Glebionis coronaria (L.) Spach. While in the South site, dominated: Avena sterilis L., Bromus diandrus Roth, Lolium perenne L., Scorpiurus muricatus L., Medicago polymorpha L., Andryala integrifolia L. and Galactites tomentosus Moench (Madejón et al., 2009).

\subsection{Sample design, collection and processing}

At both the North and South sites, we sampled soil fungal communities in five habitat types, i.e. plant covers. Three habitats were under the canopy of the selected tree species (wild olive, white poplar and stone pine). The fourth habitat was the adjacent treeless areas where natural grassland was established. For comparative purposes, we also sampled a fifth habitat. At the North site we sampled soils devoid of vegetation (bare soils) where soil amendment treatments were not effective (García-Carmona et al., 2019). At the South site, we sampled bare soil patches in a non-remediated area, covered by mining sludge, which was left for research purposes (Burgos et al., 2013).

In March 2018, topsoil samples were collected (0-5 cm depth) with a gouger auger; five soil cores were taken and mixed to make one composite sample. We collected five replicate samples for each habitat or plant cover type (wild olive, white poplar, stone pine, grassland and bare soil (without plant cover)) at both the North and South sites, making a total of 50 sampled soils (Fig. S1, B and C). Replicate samples were separated by at least $30 \mathrm{~m}$. Soil samples were taken to the laboratory and stored overnight at $4{ }^{\circ} \mathrm{C}$ until the next day when they were processed.

\subsection{Soil analyses}


A fraction of each sample was air-dried and sieved to $<2 \mathrm{~mm}$ for chemical analyses. Soil $\mathrm{pH}$ was measured in a 1:2.5 soil- $\mathrm{KCl} 1 \mathrm{M}$ suspension after 30 min of shaking. Total $\mathrm{C}$ and $\mathrm{N}$ was determined by a Flash HT Plus elemental analyser. Carbonate content was measured by the manometric method (Demolon and Leroux, 1952). The difference between total $\mathrm{C}$ and carbonates provided organic $\mathrm{C}$ content. Total $\mathrm{N}$ was considered organic $\mathrm{N}$ due to the low concentration of inorganic $\mathrm{N}$ previously analysed in the study area (López-García et al., 2018). Available P was estimated by the Olsen method (Olsen et al., 1954). X-Ray fluorescence (XRF) spectroscopy (XRF Niton ${ }^{\mathrm{TM}}$ ) was used to measure total soil elements ( $\mathrm{Ca}, \mathrm{K}, \mathrm{Zr}, \mathrm{Sr}, \mathrm{Rb}, \mathrm{Pb}, \mathrm{As}, \mathrm{Zn}, \mathrm{Cu}, \mathrm{Fe}, \mathrm{Mn}, \mathrm{Cr}, \mathrm{V}$, Ti and $\mathrm{S}$ ). Particle size distribution was determined by the hydrometer method (Gee and Bauder, 1979).

A second fraction of each sample was kept at $4{ }^{\circ} \mathrm{C}$ for one week and sieved to $<2 \mathrm{~mm}$ for microbial analyses; we expect little effects of storage conditions on fungal community structure (Rubin et al., 2013). Dehydrogenase activity and basal respiration were determined as indicators of the overall microbial activity. Dehydrogenase activity was determined following the method proposed by Trevors (1984). Soils were incubated with $0.4 \%(\mathrm{w} / \mathrm{v})$ iodonitrotetrazolium (INT), in a $1 \mathrm{M}$ TRIS-HCl buffer $\mathrm{pH} 7.5$, in the dark at $20^{\circ} \mathrm{C}$ for 20 hours. After incubation, $10 \mathrm{ml}$ of methanol were added and shaken for 1 minute and samples were filtered. The $p$-iodonitrotetrazolium formazan (INTF) produced during the incubation was measured in the extracts by determining the absorbance at 490 nm. For basal respiration analysis we used the MicroResp ${ }^{\mathrm{TM}}$ method (Campbell et al., 2003), after re-moistening the soil samples. Before measurement, soils were incubated for one week at $20^{\circ} \mathrm{C}$ and at average of $22 \%(\mathrm{w} / \mathrm{w})$ of their water holding capacity (estimated based on SPAW software, Soil Water Characteristics Module, USDA Agricultural Research Service), i.e. at soil moisture contents between 30 and 60\%, 
depending on the soils. A third fraction of each sample was immediately frozen at $-80^{\circ}$ C for molecular analysis.

\subsection{Molecular analyses}

Total DNA was extracted from the 50 soil samples with the PowerSoil ${ }^{\circledR}$ DNA Isolation Kit (MoBio Laboratories Inc., Carlsbad, CA, USA), in accordance with the manufacturer's instructions. We carried out duplicate DNA extractions for each soil sample. Library preparation and Illumina sequencing were performed by the IPBLN Genomics Core Facility (CSIC, Granada, Spain). Amplicon libraries targeting the ITS1 region were generated by a two-step PCR strategy: a gene-specific PCR followed by an indexing PCR. Both reactions were performed with KAPA HiFi HotStart ReadyMix DNA polymerase (Roche Diagnostics, West Sussex, United Kingdom). Gene-specific amplification was performed in triplicate with $10 \mathrm{ng}$ of soil-extracted DNA in a final volume of $10 \mu \mathrm{l}$. Primers ITS1F-FW (5'-CTTGGTCATTTAGAGGAAGTAA-3', Gardes and Bruns, 1993) and ITS2-Rev (5'-GCTGCGTTCTTCATCGATGC-3', White et al., 1990) were designed with Nextera overhang adapters and used at $0.3 \mu \mathrm{M}$ final concentration. These fungal primer pairs are recognized as the primary barcode for fungi (Schoch et al., 2012), however, they are biased to Ascomycota and Basidiomycota (Bellemain et al., 2010). Cycling conditions were $95^{\circ} \mathrm{C}$ for $3 \mathrm{~min}$, and then 32 PCR cycles: $95^{\circ} \mathrm{C}$ for $30 \mathrm{~s}, 52^{\circ} \mathrm{C}$ for $30 \mathrm{~s}, 72^{\circ} \mathrm{C}$ for $30 \mathrm{~s}$, and then $72^{\circ} \mathrm{C}$ for $5 \mathrm{~min}$. Triplicates of genespecific amplification were pooled together and validated through visualization on a $1.8 \%$ (w/v) agarose gel. Amplicons were then purified using NucleoMag ${ }^{\circledR}$ NGS Clean-up and Size Select Kit (Macherey-Nagel, Düren, Germany). A second PCR step attached dual combinatorial indices and Illumina sequencing adapters using Nextera XT v2 index kit. Cycling conditions were $95^{\circ} \mathrm{C}$ for $3 \mathrm{~min}$, and then $8 \mathrm{PCR}$ cycles: $95^{\circ} \mathrm{C}$ for $30 \mathrm{~s}, 55^{\circ} \mathrm{C}$ for 
$30 \mathrm{~s}, 72^{\circ} \mathrm{C}$ for $30 \mathrm{~s}$, and then $72^{\circ} \mathrm{C}$ for $5 \mathrm{~min}$. Concentration was measured on the Qubit ${ }^{\circledR}$ fluorometer (Thermo). Amplicons were diluted and pooled in an equimolecular manner and final library mix was run on a Bioanalyser HS DNA chip to verify quality and size distribution. The library pool was then diluted and denatured as recommended by Illumina MiSeq library preparation guide. The 300x2 nt paired-end sequencing was conducted on a MiSeq sequencer.

\subsection{Bioinformatic analyses}

We analysed the MiSeq sequences with amplicon sequence variant analysis pipeline, known as DADA2 v. 1.8. (Callahan et al., 2016). Briefly, forward and reverse sequences were trimmed to $260 \mathrm{bp}$ to get sequences with a quality score of at least 25 , and primers were removed. Sequences were dereplicated and the rate error model inferred and used to implement the sample inference algorithm. Forward and reverse reads were merged and chimeric sequences removed, accounting for a total of 20,320 amplicon sequence variants (ASVs). The taxonomic assignation was determined for each ASV against the UNITE database v. 7.2. (UNITE Community, 2017; Kõljalg et al., 2013). Non-fungal or unknown taxa (6\%) were removed, and 19,098 ASVs were kept. Afterwards, postclustering curation tool, known as LULU (Frøslev et al., 2017), was used to remove erroneous ASVs (a total of 4,125). Finally, in order to get Operational Taxonomic Units (OTUs) that resemble species level (see, e.g. Tedersoo et al., 2012), ASVs were clustered at $97 \%$ sequence similarity using VSEARCH v. 2.8.1. (Rognes et al., 2016) to finally define 9,428 OTUs. Functional guilds were determined using FunGUILD (Nguyen et al., 2016) and only 2,309 OTUs ( $24.5 \%$ of total) could be assigned. After that first assignment we kept those OTUs with probable or highly probable confidence ranking, and having only one guild assigned; as a result, we retained 1,283 OTUs (13.6\% of total) for the 
functional analysis. Bioinformatic analyses were carried out in R software v. 3.6.1 ( $\mathrm{R}$ development Core Team) using dada2 (Callahan et al., 2016), LULU (Frøslev et al., 2017) and phyloseq (McMurdie and Holmes, 2013).

\subsection{Statistical analyses}

An OTU abundance data matrix was constructed based on the number of reads assigned to the 9,428 fungal OTUs identified. Rarefaction curves were visualized to ensure that every sample reached plateau and hence they presented a correct coverage of the total diversity of OTUs in sampled soils. Since every sample reached plateau, there was no need to rarefy to a minimum number of reads per sample (McMurdie and Holmes, 2014).

We calculated Shannon's diversity (H), Pielou's evenness (J), OTU richness (SотU), and family richness $\left(\mathrm{S}_{\mathrm{f}}\right)$ for each sample. Beta diversity was calculated using Whittaker's betadiversity (W). Gamma (landscape) diversity of each site was estimated by the cumulative diversity of the five sampled habitats. The scale of fungal diversity by habitat and their overlapping was illustrated by Venn diagrams (http://bioinformatics.psb.ugent.be/webtools/Venn/).

Differences in fungal diversity indexes, as well as in soil abiotic and biotic variables, between plant cover type (habitat), sampling site and their interactions were tested by two-way analysis of variance (ANOVA); when they were significant, the multiple comparison between means was tested by Tukey's honest significant different (HSD) post hoc. Statistical significance threshold was fixed at $P \leq 0.05$. We tested normality with Shapiro-Wilk test, and homoscedasticity with Levene's test. When assumptions were not met, data was Box-Cox transformed or a constant variance function (varIdent function) was performed. A non-parametric Scheirer-Ray-Hare test and a Dunn's test corrected by 
Bonferroni post hoc were performed when data did not meet the assumptions. In order to explore the relationships between fungi and soil variables, Pearson's correlation tests (adjusted with Benjamini-Hochberg correction) were performed.

We tested plant cover and site factors effects on the soil fungal community composition by means of a permutation multivariate analysis of variance (PERMANOVA) implemented with adonis function (1,000 permutations). Differences in multivariate dispersion between factor levels, that could affect the results of PERMANOVA, were addressed by testing the homogeneity of variances (betadisper function). The revealed trends by PERMANOVA (effects of plant cover and site) were represented in a nonmetric multidimensional scaling (NMDS) ordination biplot. In the NMDS, we fitted significant $(P<0.05)$ soil variables with the envfit function to know the variables covarying with the fungal community structure. In addition, partial NMDS analyses were carried out separately with North and South samples to better illustrate the plant cover effects. All these analyses used Bray-Curtis distance as the measure of dissimilarity.

We conducted an indicator species analysis on the OTUs absolute abundance dataset (multipatt function) obtaining specific OTUs, through a permutation test with 999 permutations, tied to specific factor levels (Dufrêne and Legendre, 1997). The indicator values were classified according to plant cover and site factors.

Statistical analyses were carried out in R software v. 3.6.1 ( $\mathrm{R}$ development Core Team) using indicspecies (De Cáceres and Legendre, 2009), ggplot2 (Wickham, 2016), lme4 (Bates et al., 2015), nlme (Pinheiro et al., 2016), phyloseq (McMurdie and Holmes, 2013), and vegan (Oksanen et al., 2016) packages.

\subsection{Accession numbers}


Raw sequences were deposited in GenBank (https://www.ncbi.nlm.nih.gov/genbank/) under BioProject identification number PRJNA607425 and BioSamples identification numbers SAMN14132727 - SAMN14132924.

\section{RESULTS}

\subsection{Soil characteristics of fungal habitats}

Soil properties and concentration of trace elements were analysed and compared in remediated soils to study the plant cover and site effects on fungal diversity and composition. Soil properties were significantly different in terms of plant cover type and site, however no interaction between these two factors was found (Tables 1 and S2). Soil $\mathrm{pH}$ was significantly different between sites. In the North site, soils were slightly acidic in grassland areas, underneath wild olive and white polar, and strongly acidic under stone pine. In the South site, all plant-covered soils were close to neutral. In contrast, bare soils in both sites were strongly acidic. Calcium content was significantly higher in the South site and under white poplar compared to grassland and stone pine. Nitrogen content was significantly higher under white poplar than in grassland soils. Organic $\mathrm{C}$ and $\mathrm{C}: \mathrm{N}$ ratio were higher under white poplar and stone pine, when compared to grassland. Soil available $\mathrm{P}$ was significantly higher in the South site, while $\mathrm{S}$ was significantly higher in the North site (Tables 1 and S2). Dehydrogenase activity in the North site was significantly higher than in the South site. Basal respiration did not differ between the studied soils. Soil texture was significantly different between sites. The South site presented higher proportion of fine fractions (fine sand, silt and clay), while the North site registered a higher proportion of coarse sand (Tables 1 and S2). Regarding soil trace 
elements, in the South site, $\mathrm{Sr}$ and $\mathrm{Zr}$ total concentrations were higher, while $\mathrm{As}, \mathrm{Cr}, \mathrm{Cu}$, $\mathrm{Fe}, \mathrm{Mn}, \mathrm{Pb}, \mathrm{Ti}$ and $\mathrm{V}$ were significantly higher in the North site. Soil $\mathrm{Rb}$ and $\mathrm{Zn}$ did not differ between the studied soils (Tables 2 and S3).

Soil properties and trace elements were analysed in bare (non-remediated) soils (Tables 1 and 2), however they were not included in the ANOVA analysis (Tables S2 and S3) due to their lack of plant cover. These soils presented high differences with remediated soils showing the lowest values of $\mathrm{pH}, \mathrm{N}$, organic $\mathrm{C}$ and $\mathrm{C}: \mathrm{N}$ (Table 1); and the highest concentrations of $\mathrm{As}, \mathrm{Fe}, \mathrm{Pb}$ and $\mathrm{S}$ (Table 2). Regarding the soil microbial activity, dehydrogenase activity was reduced and basal respiration was under the limit of detection (Table 1).

\subsection{Soil fungal diversity}

A total of 13 fungal phyla were found in the studied soils. Ascomycota, Basidiomycota, Mortierellomycota and Chytridiomycota were the most abundant (Fig. 1). The minimum number of phyla (four) was found in the non-remediated bare soils of the South site, in contrast with the average of 11.5 phyla found in remediated soils covered by vegetation from the same site. In bare soils, the number of different families $\left(\mathrm{S}_{\mathrm{f}}\right.$, family richness) was significantly lower than in the remediated soils (Table 3). The analysis of the top abundant families $(n=20)$ showed a large variation between sites and vegetation types (Fig. S2); these 20 families represented more than $75 \%$ of the relative abundance in bare soils (Fig. S2). Grassland soils presented a higher number of families compared to bare soils and were highly even in terms of abundance. Families recorded in wild olive tree soils were similar to those found in grassland soils, except for a characteristic dominance of Trichomeriaceae and Pyronemataceae. Soils covered by poplar and pine were richer 
in fungal families, with a high dominance of Thelephoraceae, Inocybaceae, Tricholomataceae and Atheliaceae.

Plant cover had a significant influence on the diversity of soil fungal communities (OTU level) (Table 3). Species richness (SотU) was lowest in the bare soils and highest in white poplar soils, being intermediate in the soils underneath the other plant covers. Shannon (H) index was also lowest in bare soils but highest in soils covered by grassland and wild olive. Pielou's evenness was significantly affected by the interaction between plant cover and site. Fungal communities were most even in grassland soils at the North site and underneath wild olive and bare soils at the South site. Among habitats, betadiversity (W) was reduced in grassland and white poplar soils at the South site (Table 3).

There was a significant relationship between fungal diversity indexes and some soil properties (Fig. 2). When including non-remediated soils $(\mathrm{n}=50), \mathrm{pH}, \mathrm{N}$, organic $\mathrm{C}$ and $\mathrm{C}: \mathrm{N}$ ratio showed positive correlations with most of the indexes, while these correlations were negative with variables related to soil contamination, such as the content of $S$ and some trace elements ( $\mathrm{As}, \mathrm{Fe}$ and $\mathrm{Pb}$ ) (Fig. 2, A). When only soils covered by vegetation were considered $(n=40), C: N$ ratio had the most negative effect on Shannon and Simpson's indexes, while organic $\mathrm{C}$ had the most positive effect on richness (Fig. 2, B). Pielou's index correlated negatively only with $\mathrm{C}: \mathrm{N}$ ratio in the correlational analyses of both data sets.

The differences in fungal communities among habitats were reflected by the indicator analysis (Table S4) and the Venn diagrams (Fig. 3). From a total of 9,428 OTUs, 1,351 $(14 \%)$ were "indicators" (that is, specific) of a type of soil in terms of site and plant cover factors (Table S4, A). None of the species were associated to two or more groups. A list of fungal OTUs indicators of the extreme conditions in the non-remediated bare soils, covered by mine sludge, can be found in the supplementary material (Table S4, B). 
The Venn diagrams showed contrasting patterns between North and South sites (Fig. 3). Bare soils at the South site had 75 unique fungal OTUs and shared 93 OTUs with plant covered soils. Among the remediated and vegetated soils, wild olive had the lowest proportion of unique OTUs (6\% at both sites) while white poplar soils at the North (17\%) and grassland soils at the South (17\%) had the most unique OTUs.

There were clear differences in the total number of OTUs among plant covers, but they were very similar between sites (Table S5). Wild olive soils supported the lowest number of fungal OTUs while the white poplar soils showed the highest. The landscape (gamma) diversity of the soil mycobiota was over 5,000 OTUs at both sites.

\subsection{Soil fungal community composition and soil properties}

Soil fungal composition was measured by the total composition of OTUs found. In the 50 soil samples we found a total of 9,428 fungal OTUs, and the global species accumulation curve was close to saturation (Fig. S3, A), therefore the number of species found seemed to be representative of the total species established in these soils and the number of sequences was sufficient to represent the fungal diversity in this study (Fig. S3, B).

Plant cover type, sites and their interaction, as shown by PERMANOVA and NMDS ordination (Table 4 and Fig. 4), significantly affected the composition of soil fungal communities. The first axis of the NMDS ordination showed a clear separation between soil fungal communities from the North site, their habitat characterized by high availability of trace elements, sandy texture and low $\mathrm{pH}$, and those communities from the South site, characterized by higher $\mathrm{pH}, \mathrm{Ca}, \mathrm{K}$ and $\mathrm{P}$ contents and dominant clay and silt fractions in their habitats. The second axis separated fungal communities according to plant cover type. The most pronounced difference in fungal communities was seen 
between stone pine, with soils rich in organic $\mathrm{C}$ and a high $\mathrm{C}: \mathrm{N}$ ratio, and grassland fungal communities (Fig. 4). Stone pine fungal communities were discriminated by partial NMDS at both North and South sites (Fig. S4), although the correlated abiotic variables were different. A PERMANOVA analysis for each site separately showed that the plant cover effect on fungal communities was higher at the South site $\left(\mathrm{R}^{2}=0.38\right)$ compared to the North site $\left(\mathrm{R}^{2}=0.27\right)$ (Table 4$)$.

\subsection{Fungal functional diversity}

Fungi were separated in functional guilds as each fungal group exploit the resources in a characteristic way offering specific ecosystem services. The three most abundant guilds were: saprotrophs, ECM and plant pathogenic. In terms of relative abundance, saprotrophs were the most abundant functional group, especially in grassland and wild olive soils (Fig. 5, A). The second most abundant functional group was ECM fungi, which were mainly found in white poplar and stone pine soils, having over $50 \%$ abundance in the South site. The third most abundant guild was plant pathogen fungi; which were highly abundant in bare soils, although their abundance was significantly lower under grassland and tree covers (ANOVA results were $F=17.26 ; P<0.001$ ). In contrast to these three major guilds, arbuscular mycorrhizal fungi had low abundance in all studied soils.

Fungal OTUs assigned to a trophic level were $13 \%(1,283$ out of 9,428$)$ of total. Within this $13 \%$, the saprotroph guild was the richest (68\%) followed by plant pathogen and ECM guilds (Table S6). However, in terms of total reads, ECM guild accounted for over $50 \%$ of total reads, followed by saprotrophs and plant pathogens (Table S6). We studied the relationship between the abundance of these three guilds and we found significant and 
negative correlations of ECM with saprotrophs $(\mathrm{r}=-0.85 ; P<0.001)$ and with plant pathogens $(\mathrm{r}=-0.40 ; P=0.004)$; while no significant correlation was observed between the abundance of saprotrophs and plant pathogens $(\mathrm{r}=-0.13 ; P=0.365)$.

The abundance of functional groups of fungi was related with the soil variables of each habitat (Fig. S5). Thus, the abundance of saprotrophic and ECM fungi showed a positive correlation with soil $\mathrm{C}: \mathrm{N}$ ratio; the abundance of ECM fungi was correlated also with soil $\mathrm{Ca}$ content. Finally, the abundance of arbuscular mycorrhizal fungi showed a positive correlation with $\mathrm{pH}$ and content of $\mathrm{Ca}$ and clay, while correlated negatively with $\mathrm{Cu}$ concentration.

Focusing on the composition within the guild of ectomycorrhizal fungi, we applied a separate PERMANOVA analysis. Ectomycorrhizal fungal communities were significantly different depending on plant cover type $\left(F=2.20 ; P=0.001 ; \mathrm{R}^{2}=0.145\right)$, site $\left(F=2.15 ; P=0.002 ; \mathrm{R}^{2}=0.047\right)$ and on the interaction of the two factors $(F=1.57$; $\left.P=0.001 ; \mathrm{R}^{2}=0.104\right)$. These results were similar to those obtained for all fungal communities (Table 4). Ectomycorrhizal communities were more clustered in soils under white poplar and stone pine than in those under grassland and wild olive (Fig. S6). Samples of bare soils, which did not present an important ECM community, were excluded from this ECM analysis.

\section{DISCUSSION}

The recovery of soil microbial diversity is essential for the restoration of degraded lands

(Bünemann et al., 2018; Banning et al., 2011). In phytoremediated areas, the effects of 
establishing plant communities on soil microbiota is especially important for fungal communities due to their symbiotic mycorrhizal associations (Gil-Martínez et al., 2018; Op De Beeck et al., 2015; van der Heijden et al., 1998). Therefore, the plant species selected in phytoremediation, as well as their lifeform, may be of critical importance in the restoration of soil biodiversity after a large perturbation.

\subsection{Soil remediation and revegetation increases fungal diversity}

Phytoremediation seemed to favour soil microbial activity as a higher dehydrogenase activity and basal respiration was found in these soils, in comparison to non-remediated soils. Both dehydrogenase activity and respiration are sensitive indicators of trace element contamination (Hooda, 2010). Regarding fungal communities, phytoremediation enhanced fungal diversity and richness in the studied soils, probably due to the plant effect on increasing soil $\mathrm{pH}, \mathrm{N}$, organic $\mathrm{C}$ and $\mathrm{Ca}$ (Fig. 2). In non-remediated soils, the adverse abiotic conditions and the scarcity of nutrients did not boost fungal diversity and richness. Previous studies in the area found that acidic $\mathrm{pH}$ and high trace element availability were detrimental for AM (Montiel-Rozas et al., 2016) and ECM (López-García et al., 2018) fungal diversity. In phytoremediated soils, tree species identity drove a characteristic fungal community (Tedersoo et al., 2014b). White poplar and stone pine trees promoted richer fungal communities than wild olive, probably due to their symbiosis with ECM fungi and because these species promoted a higher organic $\mathrm{C}$ content in the soil (Tedersoo et al., 2014a). In agreement with Saitta et al. (2018), who found that pine trees reduced fungal diversity, in our study stone pine reduced diversity and evenness, indicating dominance by a few species. This was likely related to the negative effect of a high C:N ratio on Shannon diversity and evenness, also reported by other authors (Ni et al., 2018). 
This effect of pine trees might be related to the acidification of soil surface underneath pine, likely caused by the leaching of organic acids during the decomposition of pine litter (Madejón et al., 2018a; Richardson, 2000). Acidification of soils underneath pine trees occurred at the acidic site (North site), with a lower soil carbonate content; this acidification effect may limit colonization/growth of some fungal groups (Urbanová et al., 2015; Tedersoo et al., 2014b).

Different habitats established a unique distribution of OTUs related to differences in soil properties across plant cover types. This habitat effect has also been reported in several works (Rincón et al., 2015; Meiser et al., 2014). Despite significant differences in OTU composition, the OTU richness was consistent between the two sites (Table S5). Ectomycorrhizal fungal hosts (white poplar and stone pine) registered a higher number of OTUs and presented less variable fungal communities due to their symbiosis with ECM fungi. In contrast, wild olive had the lowest number of OTUs and a high overlapping of OTUs with other vegetated habitats. This habitat also showed the highest betadiversity in the North site, which may indicate a fungal community more dependent on the environment and affected by the soil contamination. Despite the contrasted soil conditions, the gamma diversities of fungal communities in vegetated habitats were similar (Table S5). These results contribute to the knowledge of soil microbial diversity at multiple scales (Walters and Martiny, 2020).

\subsection{Tree species identity and abiotic soil conditions influence fungal community composition}


We found that the effect of plant cover type was the main driver of the composition and structure of soil fungal communities (Table 4 and Fig. 4). In accordance, soil fungal communities have been seen strongly determined by dominant vegetation (Urbanová et al., 2015; Buée et al., 2009). As exposed above, and as found in many other works (Leff et al., 2018; Chaparro et al., 2014; Berg and Smalla, 2009), this significant influence may be related to specific changes on the abiotic/biotic environment below each tree, i.e. the "footprint". In our study, the observed changes in soil organic $\mathrm{C}$ and $\mathrm{C}: \mathrm{N}$ ratio across plant covers were clearly correlated to the diversity and the structure of soil fungal communities. Regarding the tree species effects on fungal structure, we found that Ascomycota was the most abundant phylum in all soils (except under pine in the South site), despite Basidiomycota is often dominant in forest soils (Sun et al., 2016; Zappelini et al., 2015; Tedersoo et al., 2014b; Buée et al., 2009; O’Brien et al., 2005). This pattern has been observed previously in another trace element contaminated site (NarendrulaKotha and Nkongolo, 2017) and in soils under poplar trees, both from polluted (Foulon et al., 2016) and unpolluted areas (Shakya et al., 2013). The process of vegetation succession tends to replace Ascomycota fungi, which selectively degrade cellulose over lignin, by Basidiomycota, which synthetize enzymes able to degrade complex polymers (Djemiel et al., 2017; Sun et al., 2016; Voř́š́ková and Baldrian, 2013). In the South site under the pine trees, soils presented a dominance of Basidiomycota fungi, which may be explained by the lower quality and higher complexity of pine litter (Dickie et al., 2014; Wurzburger and Hendrick, 2007; Finzi et al., 1998). This increment in Basidiomycota fungi seemed to be explained by the functional dominance of mycorrhizal taxa over saprotrophs in soils underneath pine of the South site (Fig. 5), as pines are obligated mutualists and ECM fungi belong predominantly to the Basidiomycota phylum (Peršoh, 2015; Tedersoo et al., 2010). 
Regarding soil abiotic properties, differences in soil $\mathrm{pH}$ and trace element concentration had an important effect on soil fungal communities, in accordance with previous evidences (López-García et al., 2018; Rincón et al., 2015). Different soil abiotic properties presented different effects on fungi: soil $\mathrm{pH}, \mathrm{N}$ and $\mathrm{C}$ contents correlated to fungal diversity, richness and evenness, while soil $\mathrm{pH}$, calcium and $\mathrm{C}: \mathrm{N}$ seemed to affect functional composition of the fungal communities (Fig. 2 and S5).

\subsection{Trace element contamination limits soil fungal diversity}

Non-remediated soils were characterised by a very acidic $\mathrm{pH}$ and a higher concentration of trace elements compared to remediated soils, being especially contaminated by $\mathrm{Pb}, \mathrm{As}$, Fe and S. Moreover, the lack of establishment of plant communities may explain the low $\mathrm{N}$ and organic $\mathrm{C}$ content in these soils. The high degradation on bare soils was confirmed by the reduced dehydrogenase activity and basal respiration, indicating it exists limitations on soil abiotic properties for the establishment of microbial communities (Knelman et al., 2014), as well as a reduction on the diversity and richness of the fungal communities (N. Wang et al., 2019). Contamination seemed to create a strong habitat filtering in these soils, where specific taxa were indicative of these extreme conditions (Table S4 B). Malasseziaceae and Terathosphaeriaceae families have been recognized as highly tolerant taxa to some of the most extreme environmental conditions, such as extremely acidic pH and high temperatures (Amend, 2014; Hujslová et al., 2013). Moreover, the indicator species Coniochaeta fodinicola and Fodinomyces uranophilus have been also found by Vázquez-Campos et al. (2014) in an Uranium mine ecosystem in very acidic soils with high concentrations of $\mathrm{Al}$ and Fe. These findings support the 
existence of extremophile fungi, which in these adverse soil conditions have shown to be tolerant to high trace element contamination.

\subsection{Fungal functional guilds are driven by tree species identity}

Plant composition affect the richness and the relative abundance of saprotrophic, pathogenic and mycorrhizal fungi in soils (Saitta et al., 2018; Gao et al., 2017). Saprotrophic fungi and other soil microbes play an important role in organic matter decomposition and nutrient cycling through their secretion of extracellular enzyme activities (Talbot et al., 2013). Saprotrophs were abundant in all habitat types but especially in soils under AM fungal hosts (grassland and wild olive soils). We expected AM fungi to be more abundant and diverse in soils covered by these AM host vegetation (Davison et al., 2015; Rillig, 2004), but the fungal primers used are not suitable for specifically amplifying AM (Glomeromycota) fungi (Bellemain et al., 2010). The general low abundance of AM fungi in the study site probably impeded our ability to identify differences in their diversity and abundance between pure plant AM hosts (wild olive and grasslands) and the ECM-AM dual hosts (stone pine and white poplar) (Dickie et al., 2013; Horton et al., 1998).

Plant pathogen guild was relatively abundant in non-remediated bare soils without vegetation. In these non-remediated soils, high trace element concentration reduced the capability of plant communities and their associated microorganisms to establish. On one hand, without the mutualistic association between the plant and mycorrhizal fungi, plant communities may lack the defensive capacity and induced resistance to protect themselves against plant pathogenic fungi (Van Geel et al., 2018), which could explain the presence of this guild. On the other hand, although our approach was careful when 
assigning fungal taxa as pathogenic (only the genera purely found as pathogens sensu Funguild, were recorded as such), the taxonomical identification of pathogenic fungi cannot ensure their pathogenicity ("putative plant pathogens" sensu P. Wang et al., 2019). Therefore, more research is needed to explain this pattern.

Mycorrhizal fungi is a major functional guild as these fungi perform a crucial function on plant development and in soil genesis, modulating interactions between plants and soils (Dickie et al., 2013). The highest abundance of ECM fungi in white poplar and stone pine soils is very likely to be related to the symbiosis of host trees with these fungi. Moreover, these soils registered a reduction of other guilds such as plant pathogens (P. Wang et al., 2019) and saprotrophs (Fernandez and Kennedy, 2016). The decline in the abundance of saprotrophs in soils with ECM hosts may be explained by the increase of ECM fungi, as exposed above. This reduction of saprotrophs under white poplar and stone pine soils might also contribute to the accumulation of organic matter in the soils underneath these species (Sterkenburg et al., 2018). Ectomycorrhizal fungi are in symbiosis with many dominant trees in forest ecosystems, favouring host survival by improving nutrient and water uptake (Tedersoo and Bahram, 2019). In contaminated forests, ECM fungi alleviate trace element toxicity although species composition varied along the contamination gradient (Huang et al., 2014). Among the most common ECM fungal taxa, Thelephoraceae, Inocybaceae and Pyronemataceae were well represented, as found in other studies (Horton and Bruns, 2001; Kõljalg et al., 2000). However, common Russulaceae, Cortinariaceae and Sebacinaceae taxa were rare in the study site. A common ECM species, Cenococcum geophilum was absent in our samples, in accordance with the study by López-García et al. (2018) that found that this species was only present in non-contaminated soils of the same study area. The genus Tomentella was the most widespread ECM fungus among the studied habitats, which is consistent with other 
studies reporting the high abundance of this genus, even in contaminated soils (Huang et al., 2014; Horton and Bruns, 2001; Kõljalg et al., 2000).

\subsection{Implications for management}

Twenty years after a mine spill that contaminated the study area, highly contaminated areas with acidic $\mathrm{pH}$ and low nutrient content were still present. In soils where phytoremediation was not applied, vegetation was not able to naturally establish, which likely contributed to the lower fungal diversity and relative abundance. The community in these soils was dominated by putative pathogenic fungi, which could contribute to the limited plant establishment. In contrast, where phytoremediation was applied, this strategy promoted a higher abundance diversity of fungal communities in comparison to non-remediated soils. The first intervention, sludge removal and application of different amendments, proved to be effective for the establishment of herbaceous communities. These grassland habitats support high values of fungal diversity, richness, taxonomy and functionality compared to non-remediated soils. The second intervention, planting different tree species, allowed the establishment of different habitats for fungi, further recruiting more fungal taxa, mainly within the ECM fungal guild. The selection of tree species in phytoremediated areas should take the multiple effects of these species in the ecosystem into account. In this study, white poplar seemed to be the best tree species to plant due to its positive effect on soil properties (organic matter and $\mathrm{N}$ accumulation), and its reduced acidifying effect on acidic soils, in comparison to pine trees. These positive effects on soils were associated to a higher richness and diversity of fungal communities. However, other side effects of the plantation of this tree species in contaminated areas should be further studied, such as the capacity of accumulating contaminants in aerial 
biomass (Domínguez et al., 2008). The studied ecosystem benefits from the variety of habitats and tree species established in the Guadiamar Green Corridor, as each habitat offers a refuge to diverse soil fungal community and structure.

\section{CONCLUSIONS}

In this study, we demonstrated the importance of the plant species identity in the longterm establishment of fungal species in degraded areas exposed to phytoremediation strategies. Plant cover type was the main driver of the composition and structure of soil fungal communities. Life history of the planted tree species seemed to be decisive to functional guilds of soil fungi, with ECM-host trees being key in recruiting ECM fungi. Afforestation with different tree species showed species-specific effects on soil nutrient and $\mathrm{C}$ contents which may have led to increased spatial heterogeneity in the areas with a potential to recruit a wider diversity of fungi.

\section{AUTHOR'S CONTRIBUTIONS}

MG-M, ÁL-G, MTD, CN-F and TM designed the study. MG-M, CN-F and TM conducted the sampling. MG-M and CN-F conducted the laboratory analyses. MG-M and ÁL-G conducted the data analyses. MG-M led the manuscript writing. All authors contributed critically to the drafts and gave final approval for publication.

\section{FUNDING}


This work was supported by European Union Seventh Framework Programme (FP7/2007-2013) [grant number 603498 - RECARE], and Spanish Ministry of Science, Innovation and Universities [grants number CGL2014-52858-R - RESTECO and CGL2017-82254-R - INTARSU]. MG-M was supported by Spanish Ministry of Economy and Competitiveness [grant number BES-2015-073882]. AL-G was supported by European Union's Horizon 2020 Marie Curie Individual Fellowship [grant number 708530 - DISPMIC], Spanish Ministry of Science, Innovation and Universities [grant number CGL2015-69118-C2-2-P-COEXMED-II] and University of Jaén under the Plan 6-UJA postdoctoral fellowship. MTD was supported by a postdoctoral grant by Universidad de Sevilla (V Plan Propio de Investigación) and by Spanish Ministry of Science, Innovation and Universities through the DEGRAMED project (CGL201785891-R).

\section{ACKNOWLEDGEMENTS}

We thank Francisco Javier Pardina Miñón, Cristina García de Arboleya Cañas, Patricia Reyes Puente de los Santos and José Antonio Delgado Romero for technical assistance. We thank "Servicio de Análisis IRNAS-CSIC" for chemical analysis. We thank Dr. Alicia Barroso and "Unidad de Genómica del Instituto de Parasitología y Biomedicina López-Neyra (IPBLN)" for DNA sequencing. We thank Dr. Tobias Guldberg Frøslev for guidance in bioinformatics pipelines. We thank Thomas Ashley for English proofreading.

\section{COMPETING INTERESTS}


The authors declare that they have no known competing financial interests or personal relationships that could have appeared to influence the work reported in this paper.

\section{REFERENCES}

Amend, A., 2014. From dandruff to deep-sea vents: Malassezia-like fungi are ecologically hyper-diverse. PLoS Pathogens 10, e1004277. doi:10.1371/journal.ppat.1004277

Arenas, J.M., Montes, C., Borja, F., 2003. The Guadiamar Green Corridor. From an ecological disaster to a newly designated Natural Protected Area. Seville.

Banning, N.C., Gleeson, D.B., Grigg, A.H., Grant, C.D., Andersen, G.L., Brodie, E.L., Murphy, D. V., 2011. Soil microbial community successional patterns during forest ecosystem restoration. Applied and Environmental Microbiology 77, 61586164. doi:10.1128/AEM.00764-11

Bates, D., Mächler, M., Bolker, B., Walker, S., 2015. Fitting linear mixed-effects models using lme4. Journal of Statistical Software 67, 1-48. doi:10.18637/jss.v067.i01

Bellemain, E., Carlsen, T., Brochmann, C., Coissac, E., Taberlet, P., Kauserud, H., 2010. ITS as an environmental DNA barcode for fungi: an in silico approach reveals potential PCR biases. BMC Microbiology 10, 1-9. doi:10.1186/1471-218010-189

Berg, G., Smalla, K., 2009. Plant species and soil type cooperatively shape the structure and function of microbial communities in the rhizosphere. FEMS Microbiology Ecology 68, 1-13. doi:10.1111/j.1574-6941.2009.00654.x 
Bolan, N.S., Park, J.H., Robinson, B., Naidu, R., Huh, K.Y., 2011. Phytostabilization: a green approach to contaminant containment. Advances in Agronomy 112, 145204. doi:10.1016/B978-0-12-385538-1.00004-4

Buée, M., Reich, M., Murat, C., Morin, E., Nilsson, R.H., Uroz, S., Martin, F., 2009. 454 Pyrosequencing analyses of forest soils reveal an unexpectedly high fungal diversity. New Phytologist 184, 449-456. doi:10.12957/rdc.2015.18854

Bünemann, E.K., Bongiorno, G., Bai, Z., Creamer, R.E., De Deyn, G., de Goede, R., Fleskens, L., Geissen, V., Kuyper, T.W., Mäder, P., Pulleman, M., Sukkel, W., van Groenigen, J.W., Brussaard, L., 2018. Soil quality - A critical review. Soil Biology \& Biochemistry 120, 105-125. doi:10.1016/j.soilbio.2018.01.030

Burgos, P., Madejón, P., Madejón, E., Girón, I., Cabrera, F., Murillo, J.M., 2013. Natural remediation of an unremediated soil twelve years after a mine accident: Trace element mobility and plant composition. Journal of Environmental Management 114, 36-45. doi:10.1016/j.jenvman.2012.10.060

Cabral, L., Soares, C.R.F.S., Giachini, A.J., Siqueira, J.O., 2015. Arbuscular mycorrhizal fungi in phytoremediation of contaminated areas by trace elements: mechanisms and major benefits of their applications. World Journal of Microbiology and Biotechnology 31, 1655-1664. doi:10.1007/s11274-015-1918-y

Cabrera, F., Clemente, L., Díaz Barrientos, E., López, R., Murillo, J.M., 1999. Heavy metal pollution of soils affected by the Guadiamar toxic flood. Science of the Total Environment 242, 117-129. doi:10.1016/S0048-9697(99)00379-4

Callahan, B.J., McMurdie, P.J., Rosen, M.J., Han, A.W., Johnson, A.J.A., Holmes, S.P., 2016. DADA2: high resolution sample inference from Illumina amplicon data. Nat Methods 13, 581-583. doi:10.1038/nmeth.3869.DADA2 
Campbell, C.D., Chapman, S.J., Cameron, C.M., Davidson, M.S., Potts, J.M., 2003. A rapid microtiter plate method to measure carbon dioxide evolved from carbon substrate amendments so as to determine the physiological profiles of soil microbial communities by using whole soil. Applied and Environmental Microbiology 69, 3593-3599. doi:10.1128/AEM.69.6.3593

Chaparro, J.M., Badri, D. V., Vivanco, J.M., 2014. Rhizosphere microbiome assemblage is affected by plant development. ISME Journal 8, 790-803. doi:10.1038/ismej.2013.196

Davison, J., Moora, M., Öpik, M., Adholeya, A., Ainsaar, L., Bâ, A., Burla, S., Diedhiou, A.G., Hiiesalu, I., Jairus, T., Johnson, N.C., Kane, A., Koorem, K., Kochar, M., Ndiaye, C., Pärtel, M., Reier, Ü., Saks, Ü., Singh, R., Vasar, M., Zobel, M., 2015. Global assessment of arbuscular mycorrhizal fungus diversity reveals very low endemism. Science 349, 970-973. doi:10.1126/science.aab1161

De Cáceres, M., Legendre, P., 2009. Associations between species and groups of sites: indices and statistical inference. Ecology 90, 3566-3574. doi:10.1890/08-1823.1

de Vries, F.T., Manning, P., Tallowin, J.R.B., Mortimer, S.R., Pilgrim, E.S., Harrison, K.A., Hobbs, P.J., Quirk, H., Shipley, B., Cornelissen, J.H.C., Kattge, J., Bardgett, R.D., 2012. Abiotic drivers and plant traits explain landscape-scale patterns in soil microbial communities. Ecology Letters 15, 1230-1239. doi:10.1111/j.14610248.2012.01844.x

Demolon, A., Leroux, D., 1952. Guide Pour l'Étude Expérimentale du Sol, 2nd ed, Soil Science. Gautier Villars, Paris.

Dickie, I.A., Martínez-García, L.B., Koele, N., Grelet, G.A., Tylianakis, J.M., Peltzer, D.A., Richardson, S.J., 2013. Mycorrhizas and mycorrhizal fungal communities 
throughout ecosystem development. Plant and Soil 367, 11-39.

doi:10.1007/s11104-013-1609-0

Dini-Andreote, F., Stegen, J.C., Van Elsas, J.D., Salles, J.F., 2015. Disentangling mechanisms that mediate the balance between stochastic and deterministic processes in microbial succession. Proceedings of the National Academy of Sciences of the United States of America 112, E1326-E1332. doi:10.1073/pnas. 1414261112

Djemiel, C., Grec, S., Hawkins, S., 2017. Characterization of bacterial and fungal community dynamics by high-throughput sequencing (HTS) metabarcoding during flax dew-retting. Frontiers in Microbiology 8, 1-16. doi:10.3389/fmicb.2017.02052

Domínguez, M.T., Alegre, J.M., Madejón, P., Madejón, E., Burgos, P., Cabrera, F., Marañón, T., Murillo, J.M., 2016. River banks and channels as hotspots of soil pollution after large-scale remediation of a river basin. Geoderma 261, 133-140. doi:10.1016/j.geoderma.2015.07.008

Domínguez, M.T., Marañón, T., Murillo, J.M., Schulin, R., Robinson, B.H., 2010. Nutritional status of Mediterranean trees growing in a contaminated and remediated area. Water, Air, and Soil Pollution 205, 305-321. doi:10.1007/s11270009-0075-z

Domínguez, M.T., Marañón, T., Murillo, J.M., Schulin, R., Robinson, B.H., 2008. Trace element accumulation in woody plants of the Guadiamar Valley, SW Spain: a large-scale phytomanagement case study. Environmental Pollution 152, 50-59. doi:10.1016/j.envpol.2007.05.021

Dufrêne, M., Legendre, P., 1997. Species assemblages and indicator species: the need 
for a flexible asymmetrical approach. Ecological Monographs 67, 345-366. doi:10.1890/0012-9615(1997)067[0345:SAAIST]2.0.CO;2

Fady, B., Fineschi, S., Vendramin, G., 2008. EUFORGEN Technical Guidelines for genetic conservation and use for Italian stone pine (Pinus pinea). Rome, Italy.

Fernandez, C.W., Kennedy, P.G., 2016. Revisiting the "Gadgil effect": Do interguild fungal interactions control carbon cycling in forest soils? New Phytologist 209, 1382-1394. doi:10.1111/nph.13648

Foulon, J., Zappelini, C., Durand, A., Valot, B., Girardclos, O., Blaudez, D., Chalot, M., 2016. Environmental metabarcoding reveals contrasting microbial communities at two poplar phytomanagement sites. Science of the Total Environment 571, 1230 1240. doi:10.1016/j.scitotenv.2016.07.151

Frøslev, T.G., Kjøller, R., Bruun, H.H., Ejrnæs, R., Brunbjerg, A.K., Pietroni, C., Hansen, A.J., 2017. Algorithm for post-clustering curation of DNA amplicon data yields reliable biodiversity estimates. Nature Communications 8, 1188. doi:10.1038/s41467-017-01312-x

Gao, C., Shi, N.N., Chen, L., Ji, N.N., Wu, B.W., Wang, Y.L., Xu, Y., Zheng, Y., Mi, X.C., Ma, K.P., Guo, L.D., 2017. Relationships between soil fungal and woody plant assemblages differ between ridge and valley habitats in a subtropical mountain forest. New Phytologist 213, 1874-1885. doi:10.1111/nph.14287

García-Carmona, M., García-Robles, H., Turpín Torrano, C., Fernández Ondoño, E., Lorite Moreno, J., Sierra Aragón, M., Martín Peinado, F.J., 2019. Residual pollution and vegetation distribution in amended soils 20 years after a pyrite mine tailings spill (Aznalcóllar, Spain). Science of The Total Environment 650, 933940. doi:10.1016/j.scitotenv.2018.09.092 
Gardes, M., Bruns, T.. D., 1993. ITS primers with enhanced specificity for basidiomycetes - Application to identification of mycorhizae and rusts. Molecular Ecology 2, 113-8. doi:10.1111/j.1365-294X.1993.tb00005.x

Gardi, C., Jeffery, S., Saltelli, A., 2013. An estimate of potential threats levels to soil biodiversity in EU. Global Change Biology 19, 1538-1548. doi:10.1111/gcb.12159

Gee, G.W., Bauder, J.W., 1979. Particle size analysis by hydrometer: a simplified method for routine textural analysis and and a sensitivity test of measurement parameters. Soil Science Society American Journal 43, 1004-1007. doi:10.2136/sssaj1979.03615995004300050038x

Geisen, S., Wall, D.H., van der Putten, W.H., 2019. Challenges and opportunities for soil biodiversity in the Anthropocene. Current Biology 29, R1036-R1044. doi:10.1016/j.cub.2019.08.007

Gil-Martínez, M., López-García, Á., Domínguez, M.T., Navarro-Fernández, C.M., Kjøller, R., Tibbett, M., Marañón, T., 2018. Ectomycorrhizal fungal communities and their functional traits mediate plant-soil interactions in trace element contaminated soils. Frontiers in Plant Science 9, 1682. doi:10.3389/fpls.2018.01682

Hooda, P.S., 2010. Trace elements in soils, 1st ed. Blackwell Publishing Ltd. doi:10.1002/9781444319477

Horton, T.R., Bruns, T.D., 2001. The molecular revolution in ectomycorrhizal ecology: Peeking into the black-box. Molecular Ecology 10, 1855-1871. doi:10.1046/j.0962-1083.2001.01333.x

Horton, T.R., Cázares, E., Bruns, T.D., 1998. Ectomycorrhizal, vesicular-arbuscular and 
dark septate fungal colonization of bishop pine (Pinus muricata) seedlings in the first 5 months of growth after wildfire. Mycorrhiza 8, 11-18. doi: $10.1007 / \mathrm{s} 005720050205$

Huang, J., Nara, K., Zong, K., Wang, J., Xue, S., Peng, K., Shen, Z., Lian, C., 2014. Ectomycorrhizal fungal communities associated with Masson pine (Pinus massoniana) and white oak (Quercus fabri) in a manganese mining region in Hunan Province, China. Fungal Ecology 9, 1-10. doi:10.1016/j.funeco.2014.01.001

Hujslová, M., Kubátová, A., Kostovčík, M., Kolařík, M., 2013. Acidiella bohemica gen. et sp. nov. and Acidomyces spp. (Teratosphaeriaceae), the indigenous inhabitants of extremely acidic soils in Europe. Fungal Diversity 58, 33-45. doi:10.1007/s13225012-0176-7

Knelman, J.E., Schmidt, S.K., Lynch, R.C., Darcy, J.L., Castle, S.C., Cleveland, C.C., Nemergut, D.R., 2014. Nutrient addition dramatically accelerates microbial community succession. PLoS ONE 9, e102609. doi:10.1371/journal.pone.0102609

Kõljalg, U., Dahlberg, A., Taylor, A.F.S., Larsson, E., Hallenberg, N., Stenlid, J., Larsson, K.H., Fransson, P.M., Kårén, O., Jonsson, L., 2000. Diversity and abundance of resupinate thelephoroid fungi as ectomycorrhizal symbionts in Swedish boreal forests. Molecular Ecology 9, 1985-1996. doi:10.1046/j.1365294X.2000.01105.X

Kõljalg, U., Nilsson, R.H., Abarenkov, K., Tedersoo, L., Taylor, A.F.S., Bahram, M., Bates, S.T., 2013. Towards a unified paradigm for sequence-based identification of fungi. Molecular Ecology 22, 5271-5277. doi:10.1111/mec.12481

Leff, J.W., Bardgett, R.D., Wilkinson, A., Jackson, B.G., Pritchard, W.J., De Long, J.R., 
Oakley, S., Mason, K.E., Ostle, N.J., Johnson, D., Baggs, E.M., Fierer, N., 2018. Predicting the structure of soil communities from plant community taxonomy, phylogeny, and traits. ISME Journal 12, 1794-1805. doi:10.1038/s41396-0180089-x

López-García, Á., Gil-Martínez, M., Navarro-Fernández, C.M., Kjøller, R., AzcónAguilar, C., Domínguez, M.T., Marañón, T., 2018. Functional diversity of ectomycorrhizal fungal communities is reduced by trace element contamination. Soil Biology \& Biochemistry 121, 202-211. doi:10.1016/j.soilbio.2018.03.021

Lumaret, R., Ouazzani, N., Michaud, H., Vivier, G., Deguilloux, M.F., Di Giusto, F., 2004. Allozyme variation of oleaster populations (wild olive tree) (Olea europaea L.) in the Mediterranean Basin. Heredity 92, 343-351. doi:10.1038/sj.hdy.6800430

Madejón, P., Domínguez, M.T., Gil-Martínez, M., Navarro-Fernández, C.M., MontielRozas, M.M., Madejón, E., Murillo, J.M., Cabrera, F., Marañón, T., 2018a. Evaluation of amendment addition and tree planting as measures to remediate contaminated soils: the Guadiamar case study (SW Spain). Catena 166, 34-43. doi:10.1016/j.catena.2018.03.016

Madejón, P, Domínguez, M.T., Madejón, E., Cabrera, F., Marañón, T., Murillo, J.M., 2018b. Soil-plant relationships and contamination by trace elements: a review of twenty years of experimentation and monitoring after the Aznalcóllar (SW Spain) mine accident. Science of the Total Environment 625, 50-63. doi:10.1016/j.scitotenv.2017.12.277

Madejón, P., Domínguez, M.T., Murillo, J.M., 2009. Evaluation of pastures for horses grazing on soils polluted by trace elements. Ecotoxicology 18, 417-428. doi:10.1007/s10646-009-0296-3 
Madejón, P., Marañón, T., Murillo, J.M., Robinson, B., 2004. White poplar (Populus alba) as a biomonitor of trace elements in contaminated riparian forests. Environmental Pollution 132, 145-155. doi:10.1016/j.envpol.2004.03.015

Maremmani, A., Bedini, S., Matoševic, I., Tomei, P.E., Giovannetti, M., 2003. Type of mycorrhizal associations in two coastal nature reserves of the Mediterranean basin. Mycorrhiza 13, 33-40. doi:10.1007/s00572-002-0194-5

McMurdie, P.J., Holmes, S., 2014. Waste not, want not: why rarefying microbiome data is inadmissible. PLoS Computational Biology 10, e1003531. doi:10.1371/journal.pcbi.1003531

McMurdie, P.J., Holmes, S., 2013. Phyloseq: an R package for reproducible interactive analysis and graphics of microbiome census data. PLoS ONE 8, e61217. doi:10.1371/journal.pone.0061217

Meiser, A., Bálint, M., Schmitt, I., 2014. Meta-analysis of deep-sequenced fungal communities indicates limited taxon sharing between studies and the presence of biogeographic patterns. New Phytologist 201, 623-635. doi:10.1111/nph.12532

Montiel-Rozas, M. del M., López-García, Á., Kjøller, R., Madejón, E., Rosendahl, S., 2016. Organic amendments increase phylogenetic diversity of arbuscular mycorrhizal fungi in acid soil contaminated by trace elements. Mycorrhiza 26, 575-585. doi:10.1007/s00572-016-0694-3

Mueller, R.C., Paula, F.S., Mirza, B.S., Rodrigues, J.L.M., Nüsslein, K., Bohannan, B.J.M., 2014. Links between plant and fungal communities across a deforestation chronosequence in the Amazon rainforest. ISME Journal 8, 1548-1550. doi:10.1038/ismej.2013.253 
Narendrula-Kotha, R., Nkongolo, K.K., 2017. Bacterial and fungal community structure and diversity in a mining region under long-term metal exposure revealed by metagenomics sequencing. Ecological Genetics and Genomics 2, 13-24. doi:10.1016/j.egg.2016.11.001

Nguyen, N.H., Song, Z., Bates, S.T., Branco, S., Tedersoo, L., Menke, J., Schilling, J.S., Kennedy, P.G., 2016. FUNGuild: An open annotation tool for parsing fungal community datasets by ecological guild. Fungal Ecology 20, 241-248. doi:10.1016/j.funeco.2015.06.006

Ni, Y., Yang, T., Zhang, K., Shen, C., Chu, H., 2018. Fungal communities along a small-scale elevational gradient in an alpine tundra are determined by soil carbon nitrogen ratios. Frontiers in Microbiology 9, 1815. doi:10.3389/fmicb.2018.01815

Nilsson, R.H., Anslan, S., Bahram, M., Wurzbacher, C., Baldrian, P., Tedersoo, L., 2019. Mycobiome diversity: high-throughput sequencing and identification of fungi. Nature Reviews Microbiology 17, 95-109. doi:10.1038/s41579-018-0116-y

O’Brien, H.E., Parrent, J.L., Jackson, J.A., Moncalvo, J.M., Vilgalys, R., 2005. Fungal community analysis by large-scale sequencing of environmental samples. Applied and Environmental Microbiology 71, 5544-5550. doi:10.1128/AEM.71.9.55445550.2005

Oksanen, J., Blanchet, F.G., Friendly, M., Kindt, R., Legendre, P., McGlinn, D., Minchin, P.R., O’Hara, R.B., Simpson, G.L., Solymos, P., Stevens, M.H.H., Szoecs, E., Wagner, H., 2016. vegan: Community Ecology Package. doi:10.4135/9781412971874.n145

Olsen, S.R., Cole, C. V., Watanabe, F.S., Dean, L.A., 1954. Estimation of available phosphorus in soils by extraction with sodium bicarbonate, U. S. Department of 
Agriculture. Washington, D.C.

Op De Beeck, M., Lievens, B., Busschaert, P., Rineau, F., Smits, M., Vangronsveld, J., Colpaert, J. V., 2015. Impact of metal pollution on fungal diversity and community structures. Environmental Microbiology 17, 2035-2047. doi:10.1111/14622920.12547

Palancean, I., Alba, N., Sabatti, M., Vries, S.M.G. De, 2018. EUFORGEN Technical guidelines for genetic conservation and use for white poplar (Populus alba).

Peay, K.G., Baraloto, C., Fine, P.V.A., 2013. Strong coupling of plant and fungal community structure across western Amazonian rainforests. ISME Journal 7, 1852-1861. doi:10.1038/ismej.2013.66

Peršoh, D., 2015. Plant-associated fungal communities in the light of meta'omics. Fungal Diversity 75, 1-25. doi:10.1007/s13225-015-0334-9

Pinheiro, J., Bates, D., DebRoy, S., Sarkar, D., R Core Team, 2016. nlme: linear and nonlinear mixed effects models.

Pulford, I.D., Watson, C., 2003. Phytoremediation of heavy metal-contaminated land by trees - A review. Environment International 29, 529-540. doi:10.1016/S01604120(02)00152-6

Richardson, D. (Ed.), 2000. Ecology and biogeography of Pinus. Cambridge University Press.

Rillig, M.C., 2004. Arbuscular mycorrhizae and terrestrial ecosystem processes. Ecology Letters 7, 740-754. doi:10.1111/j.1461-0248.2004.00620.x

Rincón, A., Álvarez, I.F., Pera, J., 1999. Ectomycorrhizal fungi of Pinus pinea L. in northeastern Spain. Mycorrhiza 8, 271-276. doi:10.1007/s005720050245 
Rincón, A., Santamaría-Pérez, B., Rabasa, S.G., Coince, A., Marçais, B., Buée, M., 2015. Compartmentalized and contrasted response of ectomycorrhizal and soil fungal communities of Scots pine forests along elevation gradients in France and Spain. Environmental Microbiology 17, 3009-3024. doi:10.1111/1462-2920.12894

Rodríguez-Eugenio, N., McLaughlin, M., Pennock, D., 2018. Soil pollution: a hidden reality. FAO, Rome. doi:10.1016/S0378-777X(84)80002-5

Rognes, T., Flouri, T., Nichols, B., Quince, C., Mahé, F., 2016. VSEARCH: A versatile open source tool for metagenomics. PeerJ 4, e2584. doi:10.7717/peerj.2584

Rubin, B.E.R., Gibbons, S.M., Kennedy, S., Hampton-Marcell, J., Owens, S., Gilbert, J.A., 2013. Investigating the impact of storage conditions on microbial community composition in soil samples. PLoS ONE 8, e70460. doi:10.1371/journal.pone.0070460

Saitta, A., Anslan, S., Bahram, M., Brocca, L., Tedersoo, L., 2018. Tree species identity and diversity drive fungal richness and community composition along an elevational gradient in a Mediterranean ecosystem. Mycorrhiza 28, 39-47. doi:10.1007/s00572-017-0806-8

Schoch, C.L., Seifert, K.A., Huhndorf, S., Robert, V., Spouge, J.L., Levesque, C.A., Chen, W., Bolchacova, E., Voigt, K., Crous, P.W., Miller, A.N., Wingfield, M.J., Aime, M.C., An, K.D., Bai, F.Y., Barreto, R.W., Begerow, D., Bergeron, M.J., Blackwell, M., Boekhout, T., Bogale, M., Boonyuen, N., Burgaz, A.R., Buyck, B., Cai, L., Cai, Q., Cardinali, G., Chaverri, P., Coppins, B.J., Crespo, A., Cubas, P., Cummings, C., Damm, U., de Beer, Z.W., de Hoog, G.S., Del-Prado, R., Dentinger, B., Diéguez-Uribeondo, J., Divakar, P.K., Douglas, B., Dueñas, M., Duong, T.A., Eberhardt, U., Edwards, J.E., Elshahed, M.S., Fliegerova, K., 
Furtado, M., García, M.A., Ge, Z.W., Griffith, G.W., Griffiths, K., Groenewald, J.Z., Groenewald, M., Grube, M., Gryzenhout, M., Guo, L.D., Hagen, F., Hambleton, S., Hamelin, R.C., Hansen, K., Harrold, P., Heller, G., Herrera, C., Hirayama, K., Hirooka, Y., Ho, H.M., Hoffmann, K., Hofstetter, V., Högnabba, F., Hollingsworth, P.M., Hong, S.B., Hosaka, K., Houbraken, J., Hughes, K., Huhtinen, S., Hyde, K.D., James, T., Johnson, E.M., Johnson, J.E., Johnston, P.R., Jones, E.B.G., Kelly, L.J., Kirk, P.M., Knapp, D.G., Kõljalg, U., Kovács, G.M., Kurtzman, C.P., Landvik, S., Leavitt, S.D., Liggenstoffer, A.S., Liimatainen, K., Lombard, L., Luangsa-ard, J.J., Lumbsch, H.T., Maganti, H., Maharachchikumbura, S.S.N., Martin, M.P., May, T.W., McTaggart, A.R., Methven, A.S., Meyer, W., Moncalvo, J.M., Mongkolsamrit, S., Nagy, L.G., Nilsson, R.H., Niskanen, T., Nyilasi, I., Okada, G., Okane, I., Olariaga, I., Otte, J., Papp, T., Park, D., Petkovits, T., Pino-Bodas, R., Quaedvlieg, W., Raja, H.A., Redecker, D., Rintoul, T.L., Ruibal, C., Sarmiento-Ramírez, J.M., Schmitt, I., Schüßler, A., Shearer, C., Sotome, K., Stefani, F.O.P., Stenroos, S., Stielow, B., Stockinger, H., Suetrong, S., Suh, S.O., Sung, G.H., Suzuki, M., Tanaka, K., Tedersoo, L., Telleria, M.T., Tretter, E., Untereiner, W.A., Urbina, H., Vágvölgyi, C., Vialle, A., Vu, T.D., Walther, G., Wang, Q.M., Wang, Y., Weir, B.S., Weiß, M., White, M.M., Xu, J., Yahr, R., Yang, Z.L., Yurkov, A., Zamora, J.C., Zhang, N., Zhuang, W.Y., Schindel, D., 2012. Nuclear ribosomal internal transcribed spacer (ITS) region as a universal DNA barcode marker for Fungi. Proceedings of the National Academy of Sciences of the United States of America 109, 62416246. doi:10.1073/pnas.1117018109

Shakya, M., Gottel, N., Castro, H., Yang, Z.K., Gunter, L., Labbé, J., Muchero, W., Bonito, G., Vilgalys, R., Tuskan, G., Podar, M., Schadt, C.W., 2013. A multifactor 
analysis of fungal and bacterial community structure in the root microbiome of mature Populus deltoides trees. PLoS ONE 8, e76382. doi:10.1371/journal.pone.0076382

Smith, S., Read, D., 2008. Mycorrhizal Symbiosis, 3rd ed. Academic Press, London. doi:10.1016/B978-0-12-370526-6.X5001-6

Soil Survey Staff, 2014. Keys to soil taxonomy, 12th ed, Soil Conservation Service. USDA-Natural Resources Conservation Service, Washington, DC.

Sterkenburg, E., Clemmensen, K.E., Ekblad, A., Finlay, R.D., Lindahl, B.D., 2018. Contrasting effects of ectomycorrhizal fungi on early and late stage decomposition in a boreal forest. The ISME Journal 12, 2187-2197. doi:10.1038/s41396-018$0181-2$

Sun, H., Terhonen, E., Kovalchuk, A., Tuovila, H., Chen, H., Oghenekaro, A.O., Heinonsalo, J., Kohler, A., Kasanen, R., Vasander, H., Asiegbu, F.O., 2016. Dominant tree species and soil type affect the fungal community structure in a boreal peatland forest. Applied and Environmental Microbiology 82, 2632-2643. doi:10.1128/AEM.03858-15

Sun, S., Li, S., Avera, B.N., Strahm, B.D., Badgley, B.D., 2017. Soil bacterial and fungal communities show distinct recovery patterns during forest ecosystem restoration. Applied and Environmental Microbiology 83, 1-14. doi:10.1128/AEM.00966-17

Talbot, J.M., Bruns, T.D., Smith, D.P., Branco, S., Glassman, S.I., Erlandson, S., Vilgalys, R., Peay, K.G., 2013. Independent roles of ectomycorrhizal and saprotrophic communities in soil organic matter decomposition. Soil Biology \& Biochemistry 57, 282-291. doi:10.1016/j.soilbio.2012.10.004 
Tedersoo, L., Bahram, M., 2019. Mycorrhizal types differ in ecophysiology and alter plant nutrition and soil processes. Biological Reviews 1868, 1857-1880. doi:10.1111/brv.12538

Tedersoo, L., Bahram, M., Dickie, I.A., 2014a. Does host plant richness explain diversity of ectomycorrhizal fungi? Re-evaluation of Gao et al. (2013) data sets reveals sampling effects. Molecular Ecology 23, 992-995. doi:10.1111/mec.12660

Tedersoo, L., Bahram, M., Põlme, S., Kõljalg, U., Yorou, N.S., Wijesundera, R., Ruiz, L.V., Vasco-Palacios, A.M., Thu, P.Q., Suija, A., Smith, M.E., Sharp, C., Saluveer, E., Saitta, A., Rosas, M., Riit, T., Ratkowsky, D., Pritsch, K., Põldmaa, K., Piepenbring, M., Phosri, C., Peterson, M., Parts, K., Pärtel, K., Otsing, E., Nouhra, E., Njouonkou, A.L., Nilsson, R.H., Morgado, L.N., Mayor, J., May, T.W., Majukim, L., Lodge, D.J., Lee, S.S., Larsson, K.-H., Kohout, P., Hosaka, K., Hiiesalu, I., Henkel, T.W., Harend, H., Guo, L., Greslebin, A., Gretlet, G., Geml, J., Gates, G., Dunstan, W., Dunk, C., Drenkhan, R., Dearnaley, J., Kesel, A. De, Dang, T., Chen, X., Buegger, F., Brearley, F.Q., Bonito, G., Anslan, S., Abell, S., Abarenkov, K., 2014b. Global diversity and geography of soil fungi. Science 346, 1256688. doi:10.1126/science. 1256688

Tedersoo, L., Bahram, M., Toots, M., Diédhiou, A.G., Henkel, T.W., Kjoller, R., Morris, M.H., Nara, K., Nouhra, E., Peay, K.G., Põlme, S., Ryberg, M., Smith, M.E., Kõljalg, U., 2012. Towards global patterns in the diversity and community structure of ectomycorrhizal fungi. Molecular Ecology 21, 4160-4170. doi:10.1111/j.1365-294X.2012.05602.x

Tedersoo, L., May, T.W., Smith, M.E., 2010. Ectomycorrhizal lifestyle in fungi: Global diversity, distribution, and evolution of phylogenetic lineages. Mycorrhiza 20, 
217-263. doi:10.1007/s00572-009-0274-x

Trevors, J.T., 1984. Dehydrogenase activity in soil: a comparison between the INT and TTC assay. Soil Biology \& Biochemistry 16, 673-674. doi:10.1016/00380717(84)90090-7

UNITE Community, 2017. UNITE general FASTA release [WWW Document]. URL https://doi.org/10.15156/BIO/587475

Unterseher, M., Schnittler, M., Dormann, C., Sickert, A., 2008. Application of species richness estimators for the assessment of fungal diversity. FEMS Microbiology Letters 282, 205-213. doi:10.1111/j.1574-6968.2008.01128.x

Urbanová, M., Šnajdr, J., Baldrian, P., 2015. Composition of fungal and bacterial communities in forest litter and soil is largely determined by dominant trees. Soil Biology \& Biochemistry 84, 53-64. doi:10.1016/j.soilbio.2015.02.011

van der Heijden, M.G.A., Bardgett, R.D., Van Straalen, N.M., 2008. The unseen majority: soil microbes as drivers of plant diversity and productivity in terrestrial ecosystems. Ecology Letters 11, 296-310. doi:10.1111/j.1461-0248.2007.01139.x

van der Heijden, M.G.A., Klironomos, J.N., Ursic, M., Moutoglis, P., Streitwolf-Engel, R., Boller, T., Wiemken, A., Sanders, I.R., 1998. Mycorrhizal fungal diversity determines plant biodiversity, ecosystem variability and productivity. Nature 396, 69-72. doi:10.1038/23932

van der Linde, S., Suz, L.M., Orme, C.D.L., Cox, F., Andreae, H., Asi, E., Atkinson, B., Benham, S., Carroll, C., Cools, N., De Vos, B., Dietrich, H.-P., Eichhorn, J., Gehrmann, J., Grebenc, T., Gweon, H.S., Hansen, K., Jacob, F., Kristöfel, F., Lech, P., Manninger, M., Martin, J., Meesenburg, H., Merilä, P., Nicolas, M., 
Pavlenda, P., Rautio, P., Schaub, M., Schröck, H.-W., Seidling, W., Šrámek, V., Thimonier, A., Thomsen, I.M., Titeux, H., Vanguelova, E., Verstraeten, A., Vesterdal, L., Waldner, P., Wijk, S., Zhang, Y., Žlindra, D., Bidartondo, M.I., 2018. Environment and host as large-scale controls of ectomycorrhizal fungi. Nature 558, 243-250. doi:10.1038/s41586-018-0189-9

Van Geel, M., Yu, K., Ceulemans, T., Peeters, G., van Acker, K., Geerts, W., Ramos, M.A., Serafim, C., Kastendeuch, P., Najjar, G., Ameglio, T., Ngao, J., Saudreau, M., Waud, M., Lievens, B., Castro, P.M., Somers, B., Honnay, O., 2018. Variation in ectomycorrhizal fungal communities associated with Silver linden $(<i>$ Tilia tomentosa $<\mathrm{i} />$ ) within and across urban areas. FEMS Microbiology Ecology 94. doi:10.1093/femsec/fiy207

Vázquez-Campos, X., Kinsela, A.S., Waite, T.D., Collins, R.N., Neilan, B.A., 2014. Fodinomyces uranophilus gen. nov. sp. nov. and Coniochaeta fodinicola sp. nov., two uranium mine-inhabiting Ascomycota fungi from northern Australia. Mycologia 106, 1073-1089. doi:10.3852/14-013

Veresoglou, S.D., Halley, J.M., Rillig, M.C., 2015. Extinction risk of soil biota. Nature Communications 6, 1-10. doi:10.1038/ncomms9862

Vořřšková, J., Baldrian, P., 2013. Fungal community on decomposing leaf litter undergoes rapid successional changes. ISME Journal 7, 477-486. doi:10.1038/ismej.2012.116

Walters, K., Martiny, J., 2020. Alpha-, beta-, and gamma-diversity of bacteria varies across global habitats. BioRxiv. doi:10.1101/2020.05.15.097758

Wang, L., Ji, B., Hu, Y., Liu, R., Sun, W., 2017. A review on in situ phytoremediation of mine tailings. Chemosphere 184, 594-600. 
doi:10.1016/j.chemosphere.2017.06.025

Wang, N., Wang, A., Xie, J., He, M., 2019. Responses of soil fungal and archaeal communities to environmental factors in an ongoing antimony mine area. Science of the Total Environment 652, 1030-1039. doi:10.1016/j.scitotenv.2018.10.300

Wang, P., Chen, Y., Sun, Y., Tan, S., Zhang, S., Wang, Z., Zhou, J., Zhang, G., Shu, W., Luo, C., Kuang, J., 2019. Distinct biogeography of different fungal guilds and their associations with plant species richness in forest ecosystems. Frontiers in Ecology and Evolution 7, 1-13. doi:10.3389/fevo.2019.00216

White, T.J., Bruns, T., Lee, S., Taylor, J.W., 1990. Amplification and direct sequencing of fungal ribosomal RNA genes for phylogenetics, in: Innis, M.A., Gelfand, D.H., Sninsky, J.J., White, T.J. (Eds.), PCR Protocols: A Guide to Methods and Applications. Academic Press, Inc., New York.

Wickham, H., 2016. ggplot2: elegant graphics for data analysis. Springer-Verlag, New York.

Zappelini, C., Karimi, B., Foulon, J., Lacercat-Didier, L., Maillard, F., Valot, B., Blaudez, D., Cazaux, D., Gilbert, D., Yergeau, E., Greer, C., Chalot, M., 2015. Diversity and complexity of microbial communities from a chlor-alkali tailings dump. Soil Biology \& Biochemistry 90, 101-110. doi:10.1016/j.soilbio.2015.08.008 
Table 1. Soil properties at two sites and five plant cover types. Values are mean and standard error of soil (0-5 cm depth) samples. Abbreviations are orgC: organic carbon; DH: Dehydrogenase activity; BR: Basal respiration; LOD: Limit of detection.

\begin{tabular}{|c|c|c|c|c|c|c|}
\hline \multirow{2}{*}{$\begin{array}{l}\text { Soil } \\
\text { Properties } \\
\text { (unit) }\end{array}$} & \multirow[t]{2}{*}{ Site } & \multicolumn{5}{|l|}{ Plant cover } \\
\hline & & $\begin{array}{l}\text { Bare soil } \\
\text { (Control) }\end{array}$ & Grassland & Olea europaea & Populus alba & Pinus pinea \\
\hline \multirow[t]{2}{*}{$\mathrm{pH}$} & North & $3.22 \pm 0.11$ & $5.68 \pm 0.16$ & $5.59 \pm 0.16$ & $5.71 \pm 0.20$ & $4.43 \pm 0.49$ \\
\hline & South & $2.55 \pm 0.11$ & $6.93 \pm 0.04$ & $6.90 \pm 0.05$ & $6.89 \pm 0.04$ & $6.98 \pm 0.06$ \\
\hline $\mathrm{N}$ & North & $0.070 \pm 0.012$ & $0.198 \pm 0.041$ & $0.233 \pm 0.028$ & $0.301 \pm 0.030$ & $0.233 \pm 0.030$ \\
\hline$(\%)$ & South & $0.137 \pm 0.023$ & $0.180 \pm 0.019$ & $0.246 \pm 0.022$ & $0.265 \pm 0.037$ & $0.192 \pm 0.021$ \\
\hline $\operatorname{orgC}$ & North & $0.67 \pm 0.09$ & $2.19 \pm 0.41$ & $3.02 \pm 0.37$ & $3.89 \pm 0.37$ & $3.76 \pm 0.29$ \\
\hline$(\%)$ & South & $0.79 \pm 0.13$ & $2.53 \pm 0.32$ & $3.34 \pm 0.35$ & $3.89 \pm 0.45$ & $3.48 \pm 0.48$ \\
\hline \multirow[t]{2}{*}{$\mathrm{C}: \mathrm{N}$} & North & $9.92 \pm 1.05$ & $11.37 \pm 0.31$ & $12.97 \pm 0.29$ & $12.93 \pm 0.26$ & $16.68 \pm 1.13$ \\
\hline & South & $5.85 \pm 0.27$ & $14.63 \pm 2.44$ & $13.53 \pm 0.75$ & $14.86 \pm 0.47$ & $17.98 \pm 1.38$ \\
\hline $\mathrm{P}$ & North & $6.04 \pm 1.12$ & $5.32 \pm 0.85$ & $6.56 \pm 0.85$ & $10.36 \pm 1.38$ & $10.16 \pm 2.58$ \\
\hline$\left(\mathrm{mg} \mathrm{kg}^{-1}\right)$ & South & $2.00 \pm 0.51$ & $13.16 \pm 2.36$ & $24.62 \pm 4.70$ & $18.78 \pm 2.79$ & $14.6 \pm 1.45$ \\
\hline $\mathrm{Ca}$ & North & $12774 \pm 813$ & $12187 \pm 481$ & $12096 \pm 435$ & $16328 \pm 1068$ & $12637 \pm 1821$ \\
\hline$\left(\mathrm{mg} \mathrm{kg}^{-1}\right)$ & South & $19024 \pm 1225$ & $52912 \pm 3238$ & $60111 \pm 2681$ & $62866 \pm 2460$ & $53071 \pm 3147$ \\
\hline K & North & $13487 \pm 329$ & $15101 \pm 645$ & $14254 \pm 450$ & $13927 \pm 568$ & $13818 \pm 705$ \\
\hline$\left(\mathrm{mg} \mathrm{kg}^{-1}\right)$ & South & $12673 \pm 100$ & $15018 \pm 456$ & $15274 \pm 709$ & $15597 \pm 336$ & $14383 \pm 613$ \\
\hline S & North & $12332 \pm 2097$ & $1795 \pm 330$ & $2147 \pm 402$ & $4324 \pm 1715$ & $4350 \pm 1301$ \\
\hline$\left(\mathrm{mg} \mathrm{kg}^{-1}\right)$ & South & $47928 \pm 2811$ & $1000 \pm 168$ & $880 \pm 129$ & $994 \pm 143$ & $831 \pm 76$ \\
\hline DH & North & $0.87 \pm 0.13$ & $3.95 \pm 0.57$ & $5.03 \pm 0.29$ & $5.36 \pm 0.66$ & $4.01 \pm 0.66$ \\
\hline$\left(\mu \mathrm{g}\right.$ INTF $\left.g^{-1} h^{-1}\right)$ & South & $0.20 \pm 0.05$ & $2.90 \pm 0.14$ & $3.49 \pm 0.43$ & $3.96 \pm 0.37$ & $3.35 \pm 0.34$ \\
\hline $\mathrm{BR}$ & North & $<\mathrm{LOD}$ & $2.05 \pm 0.74$ & $2.8 \pm 0.60$ & $3.04 \pm 1.07$ & $2.19 \pm 0.81$ \\
\hline$\left(\mu \mathrm{g} \mathrm{CO}_{2}-\mathrm{C} \mathrm{g}^{-1} \mathrm{~h}^{-1}\right)$ & South & $<$ LOD & $2.92 \pm 0.32$ & $3.46 \pm 0.20$ & $3.49 \pm 0.39$ & $3.47 \pm 0.19$ \\
\hline Fine sand & North & $24.02 \pm 2.82$ & $21.74 \pm 4.63$ & $21.72 \pm 5.73$ & $16.78 \pm 3.65$ & $18.32 \pm 5.11$ \\
\hline (\%) & South & $21.96 \pm 0.94$ & $27.08 \pm 3.04$ & $28.30 \pm 3.47$ & $26.20 \pm 2.33$ & $22.90 \pm 1.98$ \\
\hline Coarse sand & North & $44.40 \pm 7.49$ & $40.52 \pm 9.02$ & $47.76 \pm 9.87$ & $55.16 \pm 8.50$ & $49.96 \pm 8.81$ \\
\hline (\%) & South & $19.14 \pm 1.93$ & $20.20 \pm 4.65$ & $13.96 \pm 4.30$ & $19.32 \pm 1.58$ & $23.82 \pm 5.94$ \\
\hline Silt & North & $20.16 \pm 3.02$ & $27.72 \pm 3.31$ & $24.36 \pm 3.93$ & $20.04 \pm 4.02$ & $22.04 \pm 2.64$ \\
\hline$(\%)$ & South & $46.00 \pm 4.51$ & $33.28 \pm 2.20$ & $36.18 \pm 1.62$ & $33.26 \pm 1.46$ & $32.28 \pm 2.24$ \\
\hline Clay & North & $11.44 \pm 2.01$ & $9.98 \pm 1.72$ & $6.10 \pm 0.78$ & $7.96 \pm 2.32$ & $9.64 \pm 2.07$ \\
\hline$(\%)$ & South & $12.84 \pm 1.98$ & $19.42 \pm 1.57$ & $21.50 \pm 0.62$ & $21.20 \pm 1.81$ & $20.96 \pm 1.97$ \\
\hline
\end{tabular}


Table 2. Concentration of trace elements $\left(\mathrm{mg} \mathrm{kg}^{-1}\right)$ in soil samples $(0-5 \mathrm{~cm}$ depth) from two sites and five plant cover types. Values are mean and standard error.

\begin{tabular}{|c|c|c|c|c|c|c|}
\hline \multirow{2}{*}{$\begin{array}{l}\text { Soil } \\
\text { trace } \\
\text { elements }\end{array}$} & \multirow[t]{2}{*}{ Site } & \multicolumn{5}{|l|}{ Plant cover } \\
\hline & & $\begin{array}{l}\text { Bare soil } \\
\text { (Control) }\end{array}$ & Grassland & Olea europaea & Populus alba & Pinus pinea \\
\hline \multirow[t]{2}{*}{ As } & North & $196 \pm 32$ & $92.8 \pm 7.6$ & $105 \pm 9$ & $112 \pm 26$ & $121 \pm 20$ \\
\hline & South & $957 \pm 141$ & $44.0 \pm 7.6$ & $44.7 \pm 6.4$ & $39.9 \pm 6.4$ & $37.6 \pm 3.3$ \\
\hline \multirow[t]{2}{*}{$\mathrm{Cr}$} & North & $41.00 \pm 11.07$ & $46.59 \pm 8.04$ & $30.92 \pm 4.57$ & $44.77 \pm 10.11$ & $43.86 \pm 2.85$ \\
\hline & South & $30.92 \pm 1.51$ & $25.12 \pm 3.23$ & $30 \pm 4.78$ & $32.85 \pm 3.34$ & $32.43 \pm 2.83$ \\
\hline \multirow[t]{2}{*}{$\mathrm{Cu}$} & North & $124 \pm 8$ & $144 \pm 10$ & $159 \pm 8$ & $143 \pm 11$ & $135 \pm 7$ \\
\hline & South & $98.1 \pm 13.5$ & $54.5 \pm 8.7$ & $53.3 \pm 2.8$ & $50.2 \pm 7.4$ & $52.3 \pm 5.6$ \\
\hline \multirow[t]{2}{*}{$\mathrm{Fe}$} & North & $47110 \pm 3776$ & $41941 \pm 2164$ & $42006 \pm 1939$ & $39664 \pm 3382$ & $39763 \pm 1395$ \\
\hline & South & $96279 \pm 9864$ & $21812 \pm 1756$ & $23971 \pm 1475$ & $22430 \pm 1708$ & $23220 \pm 1611$ \\
\hline \multirow[t]{2}{*}{$\mathrm{Mn}$} & North & $366 \pm 22$ & $672 \pm 56$ & $599 \pm 55$ & $567 \pm 60$ & $486 \pm 55$ \\
\hline & South & $127 \pm 10$ & $331 \pm 32$ & $335 \pm 27$ & $322 \pm 33$ & $336 \pm 24$ \\
\hline \multirow[t]{2}{*}{$\mathrm{Pb}$} & North & $290 \pm 59$ & $167 \pm 15$ & $168 \pm 15$ & $174 \pm 4$ & $188 \pm 19$ \\
\hline & South & $5715 \pm 2514$ & $92.7 \pm 14.9$ & $93.3 \pm 12.9$ & $80.2 \pm 13.2$ & $75.7 \pm 5.3$ \\
\hline \multirow[t]{2}{*}{$\mathrm{Rb}$} & North & $58.19 \pm 1.67$ & $68.56 \pm 3.81$ & $67.44 \pm 0.50$ & $61.75 \pm 2.46$ & $63.93 \pm 1.73$ \\
\hline & South & $64.81 \pm 2.63$ & $65.3 \pm 1.84$ & $69.29 \pm 1.83$ & $66.15 \pm 2.48$ & $66.04 \pm 2.65$ \\
\hline \multirow[t]{2}{*}{$\mathrm{Sr}$} & North & $109 \pm 4$ & $115 \pm 2$ & $118 \pm 3$ & $113 \pm 3$ & $105 \pm 4$ \\
\hline & South & $103 \pm 4$ & $115 \pm 3$ & $127 \pm 3$ & $123 \pm 4$ & $120 \pm 5$ \\
\hline \multirow[t]{2}{*}{$\mathrm{Ti}$} & North & $4873 \pm 194$ & $5128 \pm 396$ & $4957 \pm 334$ & $5110 \pm 390$ & $4270 \pm 347$ \\
\hline & South & $3251 \pm 131$ & $3569 \pm 177$ & $3308 \pm 185$ & $3471 \pm 137$ & $3460 \pm 218$ \\
\hline \multirow[t]{2}{*}{$\mathrm{V}$} & North & $125 \pm 7$ & $135 \pm 5$ & $124 \pm 6$ & $124 \pm 8$ & $110 \pm 6$ \\
\hline & South & $82.6 \pm 6.0$ & $88.8 \pm 6.8$ & $90.7 \pm 5.5$ & $98.3 \pm 5.3$ & $89.3 \pm 7.8$ \\
\hline \multirow[t]{2}{*}{$\mathrm{Zn}$} & North & $153 \pm 15$ & $255 \pm 20$ & $250 \pm 6$ & $310 \pm 27$ & $249 \pm 33$ \\
\hline & South & $187 \pm 46$ & $251 \pm 31$ & $252 \pm 16$ & $263 \pm 33$ & $239 \pm 23$ \\
\hline \multirow[t]{2}{*}{$\mathrm{Zr}$} & North & $223 \pm 9$ & $250 \pm 24$ & $223 \pm 11$ & $202 \pm 24$ & $226 \pm 16$ \\
\hline & South & $254 \pm 24$ & $279 \pm 12$ & $239 \pm 6$ & $228 \pm 14$ & $250 \pm 11$ \\
\hline
\end{tabular}


Table 3. Mean and standard error with two-way analysis of variance (ANOVA) statistic F with effects of plant cover (Bare soil, Grassland, Olea europaea, Populus alba and Pinus pinea) $(d f=4)$, site (North and South) $(d f=1)$ and their interaction $(d f=4)$ on fungal biodiversity indexes (n =50). Tukey's honest significant difference (HSD) post hoc. Differences across plant cover types were indicated by lowercase letters. Asterisks indicate the significance level $\left({ }^{*} P \leq 0.05 ; * * \leq 0.01\right.$; *** $\left.P \leq 0.001\right)$. $\alpha$ : VarIdent function used to meet the homoscedasticity assumption. H: Shannon index; J: Pielou's evenness; Sотu: OTUs richness; $\mathrm{S}_{\mathrm{f}}$ : Family`s richness; W: Whittaker's betadiversity.

\begin{tabular}{|c|c|c|c|c|c|c|c|c|c|c|}
\hline \multirow[t]{2}{*}{ Index } & \multirow[t]{2}{*}{ Site } & \multicolumn{5}{|l|}{ Plant cover } & \multicolumn{4}{|l|}{ ANOVA } \\
\hline & & Bare soil & Grassland & Olea europaea & Populus alba & Pinus pinea & $\begin{array}{l}\text { Plant } \\
\text { cover }\end{array}$ & Site & Interaction & \\
\hline \multirow[t]{2}{*}{$\mathrm{H}$} & North & $2.97 \pm 0.21 \mathbf{c}$ & $4.75 \pm 0.20 \mathbf{a}$ & $4.53 \pm 0.10 \mathbf{a}$ & $4.70 \pm 0.12 \mathbf{a}$ & $3.87 \pm 0.30 \mathbf{b}$ & $30.80 * * * *$ & 0.49 & 1.03 & $\alpha$ \\
\hline & South & $2.95 \pm 0.5$ & $4.83 \pm 0.12$ & $4.69 \pm 0.13$ & $4.16 \pm 0.25$ & $3.78 \pm 0.25$ & & & & \\
\hline \multirow[t]{2}{*}{ J } & North & $0.533 \pm 0.032$ & $0.715 \pm 0.015$ & $0.693 \pm 0.013$ & $0.675 \pm 0.016$ & $0.564 \pm 0.047$ & $13.32 * * *$ & 0.48 & $10.40 * * *$ & $\alpha$ \\
\hline & South & $0.765 \pm 0.028$ & $0.692 \pm 0.009$ & $0.762 \pm 0.020$ & $0.591 \pm 0.039$ & $0.545 \pm 0.024$ & & & & \\
\hline \multirow[t]{2}{*}{$\mathrm{S}_{\text {отU }}$} & North & $303 \pm 72 \mathbf{c}$ & $835 \pm 198 \mathbf{a b}$ & $706 \pm 70 b$ & $1076 \pm 113 \mathbf{a}$ & $995 \pm 113 \mathbf{a b}$ & $15.88 * * *$ & 0.03 & 1.04 & \\
\hline & South & $51.2 \pm 9.0$ & $1095 \pm 101$ & $599 \pm 234$ & $1168 \pm 99$ & $1069 \pm 193$ & & & & \\
\hline \multirow[t]{2}{*}{$S_{\mathrm{f}}$} & North & $62.6 \pm 9.7$ & $95.6 \pm 8.0$ & $101.8 \pm 5.5$ & $124.0 \pm 6.6$ & $123.8 \pm 6.6$ & $32.02 * * *$ & 0.05 & 3.74* & \\
\hline & South & $19.8 \pm 1.9$ & $111.0 \pm 5.5$ & $95.0 \pm 18.1$ & $141.0 \pm 6.8$ & $134.6 \pm 12.4$ & & & & \\
\hline \multirow[t]{2}{*}{ W } & North & $0.429 \pm 0.041$ & $0.430 \pm 0.029$ & $0.377 \pm 0.010$ & $0.388 \pm 0.017$ & $0.405 \pm 0.015$ & $4.97 * *$ & $<0.01$ & 2.70* & \\
\hline & South & $0.424 \pm 0.026$ & $0.330 \pm 0.012$ & $0.410 \pm 0.030$ & $0.334 \pm 0.013$ & $0.364 \pm 0.011$ & & & & \\
\hline
\end{tabular}


Table 4. Permutational multivariate analysis of variance (PERMANOVA) of the effect of plant cover and site on the distribution of fungal communities $(n=40)$ in soil. In bold, statistically significant relationships $(P<0.05)$.

\begin{tabular}{lllllll}
\hline & Df & SS & MS & F.Model & $\mathrm{R}^{2}$ & Pr $(>\mathrm{F})$ \\
\hline Plant cover & 3 & 2.55 & 0.85 & 3.44 & 0.191 & $<\mathbf{0 . 0 0 1}$ \\
Site & 1 & 1.56 & 1.56 & 6.33 & 0.117 & $<\mathbf{0 . 0 0 1}$ \\
Interaction & 3 & 1.35 & 0.45 & 1.82 & 0.101 & $<\mathbf{0 . 0 0 1}$ \\
\hline North site & \multicolumn{7}{l}{0} & & \\
\hline Plant cover & 3 & 1.55 & 0.52 & 2.00 & \\
\hline South site & \multicolumn{7}{l}{0.272} & $\mathbf{0 . 0 0 1}$ \\
\hline Plant cover & 3 & 2.35 & 0.78 & 3.33 & 0.385 & $<\mathbf{0 . 0 0 1}$ \\
\hline Df, degrees of freedom; SS, sum of squares; MS, Mean squares; Pr value by permutation.
\end{tabular}




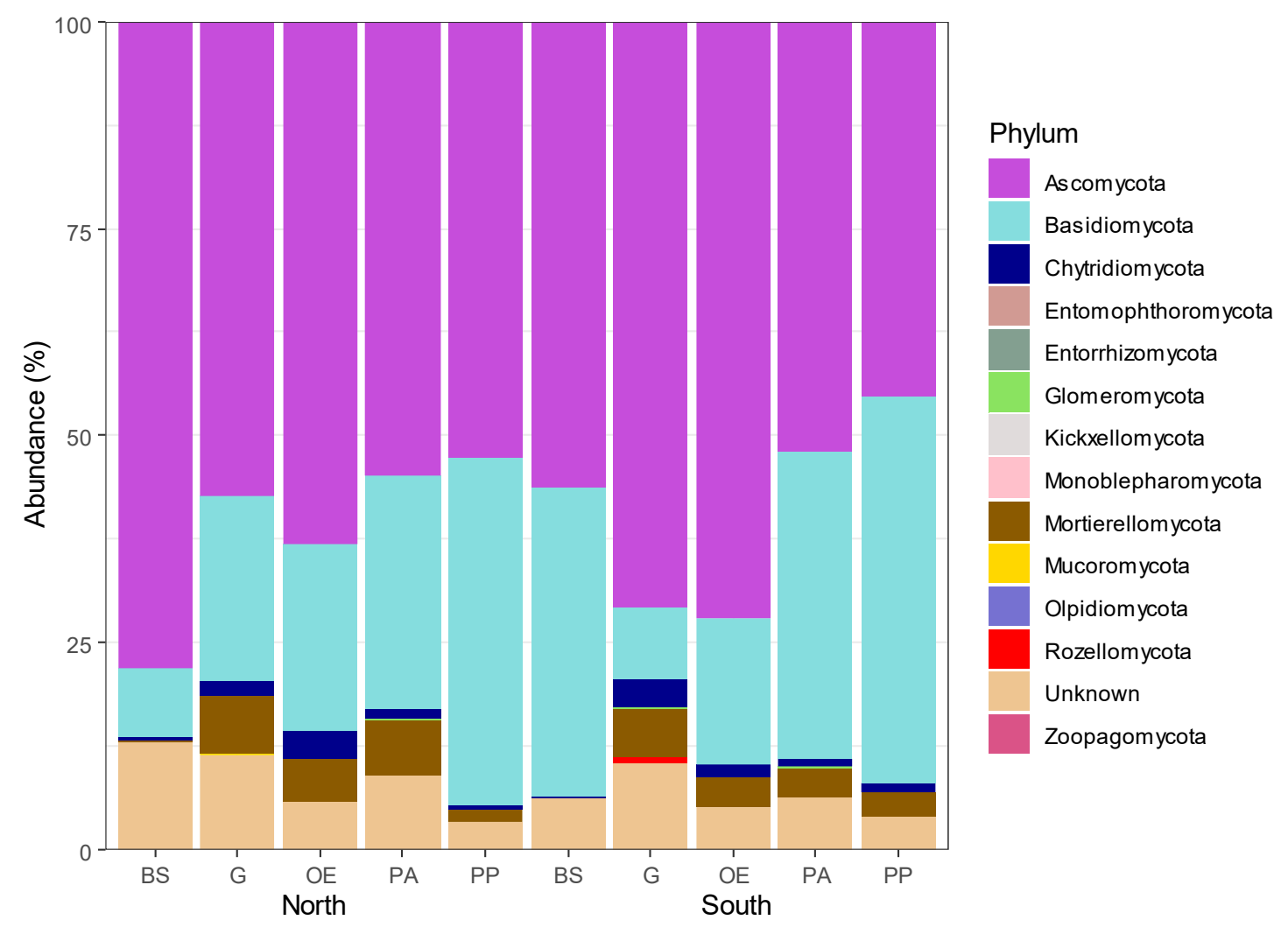

Figure 1. Relative abundance of fungal phyla in the 10 habitat types according to plant cover $(\mathrm{BS}=$ Bare soil, $\mathrm{G}=$ Grassland, $\mathrm{OE}=$ Olea europaea, $\mathrm{PA}=$ Populus alba, $\mathrm{PP}=$ Pinus pinea) and site (North, South) factors. 


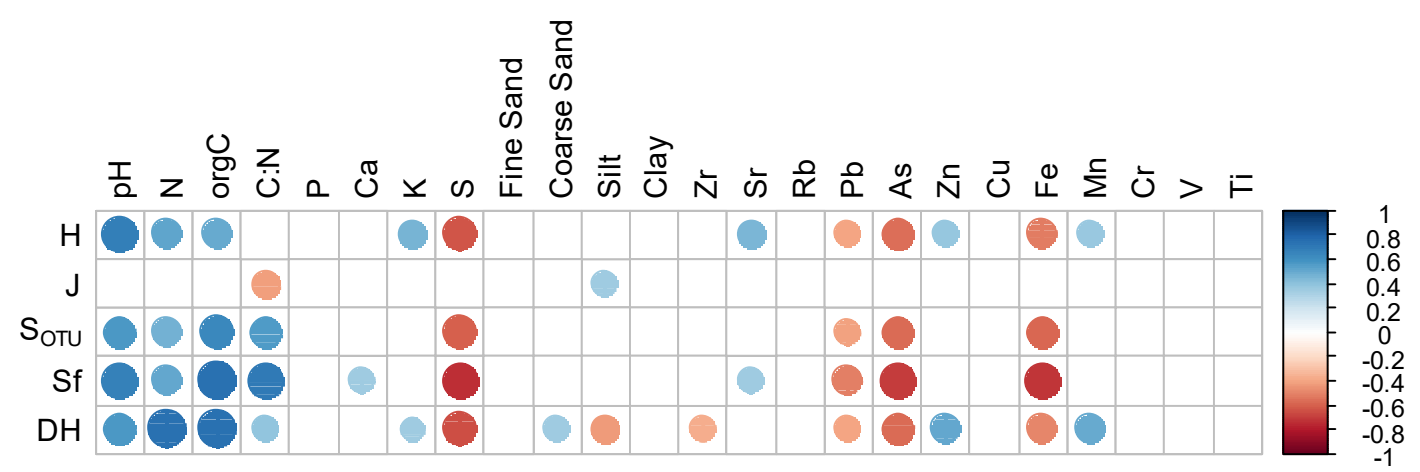

B

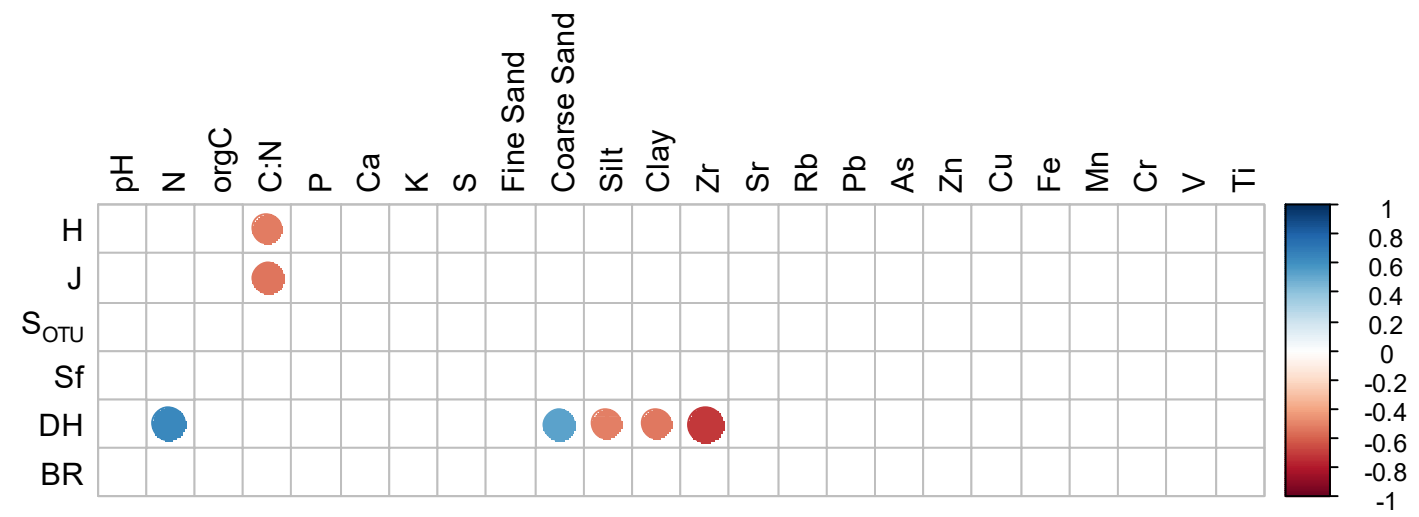

Figure 2. Pearson's correlation coefficient between diversity indexes, dehydrogenase activity $(\mathrm{DH})$ and basal respiration $(\mathrm{BR})$ and soil abiotic variables $\mathrm{A})$ including bare soil $(\mathrm{n}=50)$ and $\mathrm{B})$ excluding bare soil $(\mathrm{n}=40)$. Circles indicate significant differences $(P<$ $0.05)$; blue and red colours indicate positive and negative correlations, respectively. 

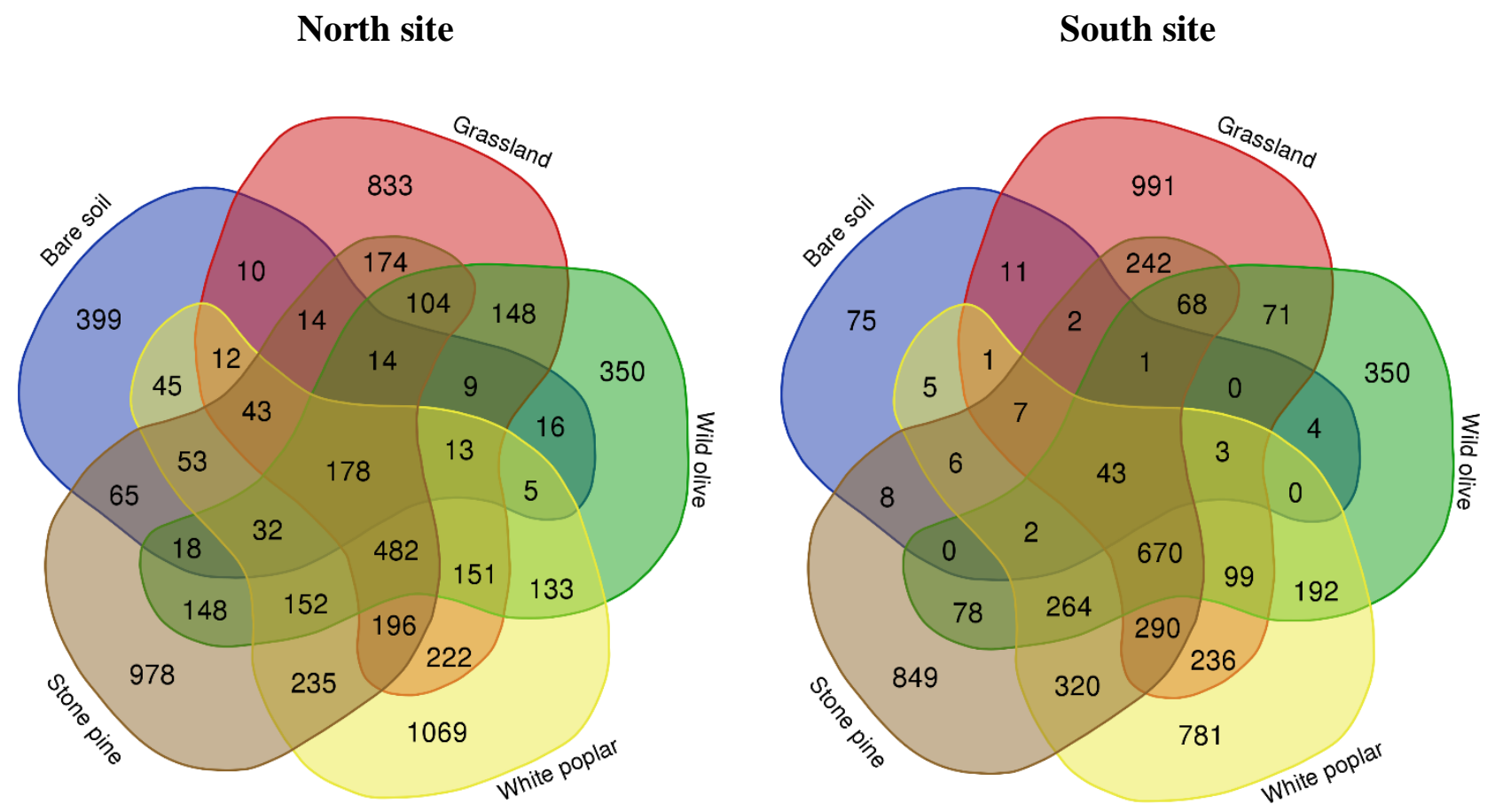

Figure 3. Venn diagrams of operational taxonomic units (OTUs) distribution among the samples according to plant cover factor. Numbers indicate the number of unique or shared OTUs. Each diagram corresponds to a different site, North and South. 


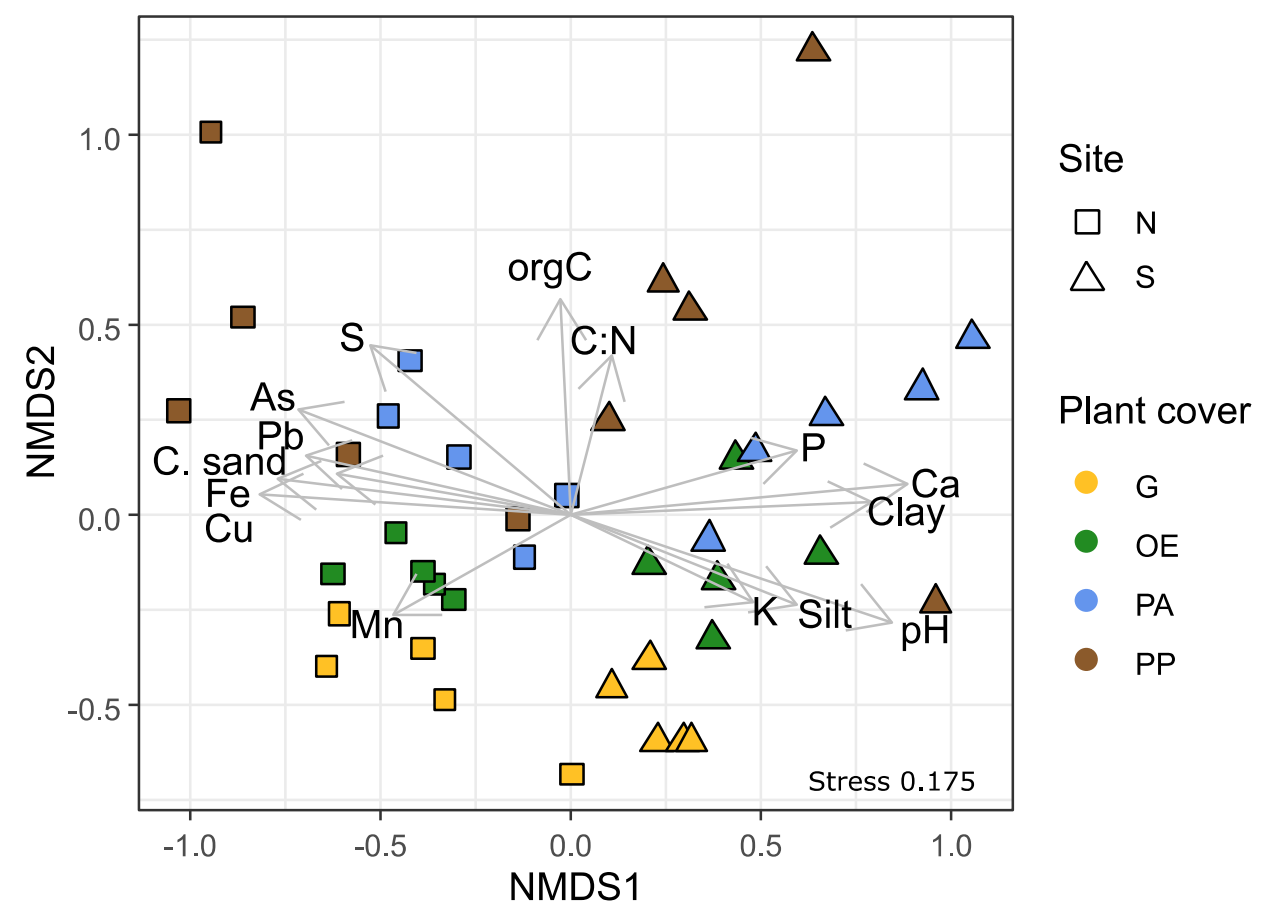

Figure 4. Non-metric multidimensional scaling (NMDS) ordination biplot of fungal communities. Symbols according to site ( $\mathrm{N}=$ North (square) and $\mathrm{S}=$ South (triangle)) and plant cover $(\mathrm{G}=$ Grassland, $\mathrm{OE}=$ Olea europaea, $\mathrm{PA}=$ Populus alba, $\mathrm{PP}=$ Pinus pinea). Significant $(P<0.05)$ soil properties are presented as arrows. 

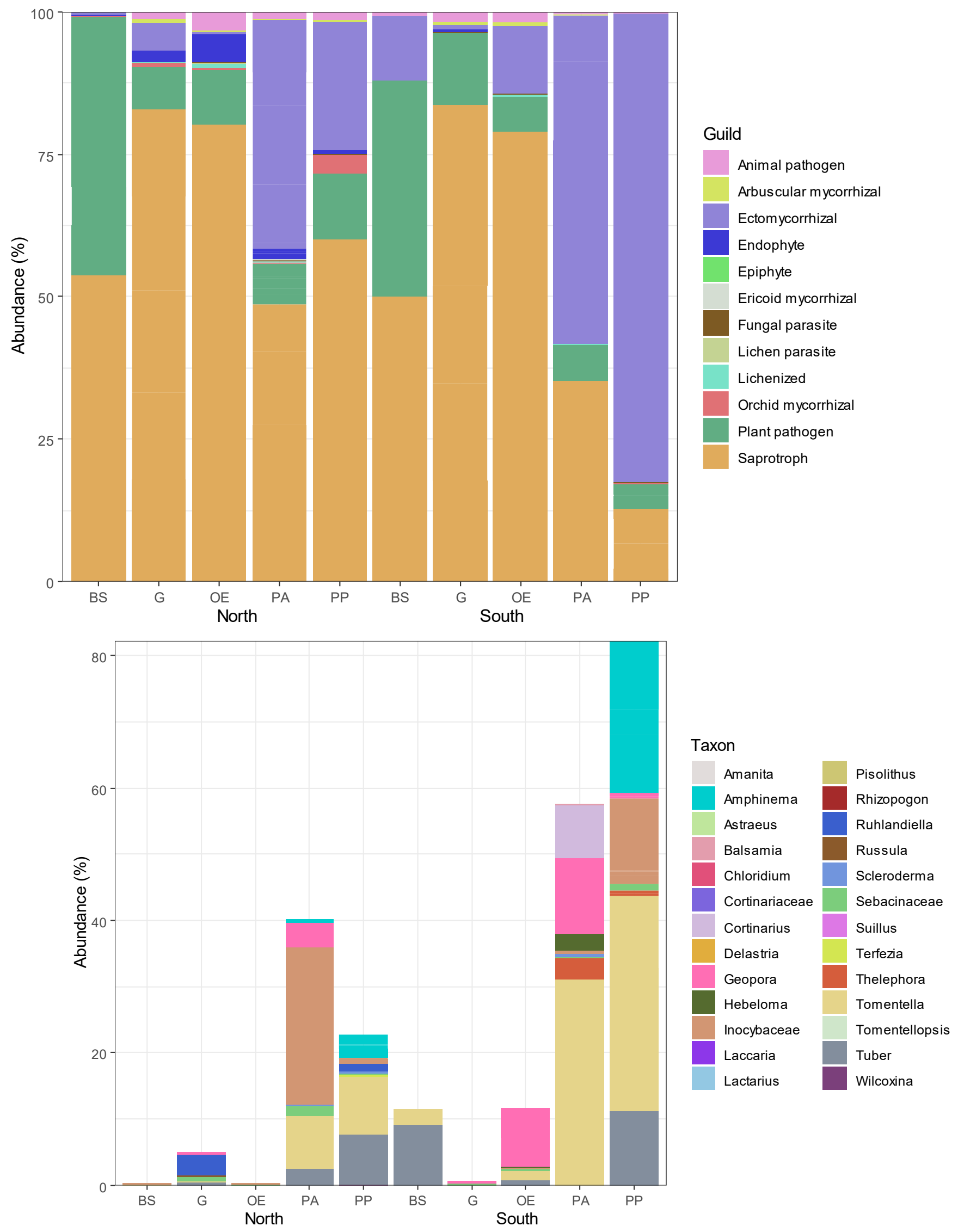

Figure 5. Relative abundance of A) fungal guilds and B) ECM fungal taxa in the 10 habitat types according to plant cover $(\mathrm{BS}=\mathrm{Bare}$ soil, $\mathrm{G}=$ Grassland, $\mathrm{OE}=$ Olea europaea, $\mathrm{PA}=$ Populus alba, $\mathrm{PP}=$ Pinus pinea) and site (North, South) factors. 


\section{Supplementary Material}

Article title: Soil fungal diversity and functionality are driven by plant species used in phytoremediation

Authors: Gil-Martínez, Marta*; López-García, Álvaro; Domínguez, María T.; Kjøller, Rasmus; Navarro-Fernández, Carmen M.; Rosendahl, Søren; Marañón, Teodoro

* Correspondence: Marta Gil-Martínez; marta.gil@irnas.csic.es

A

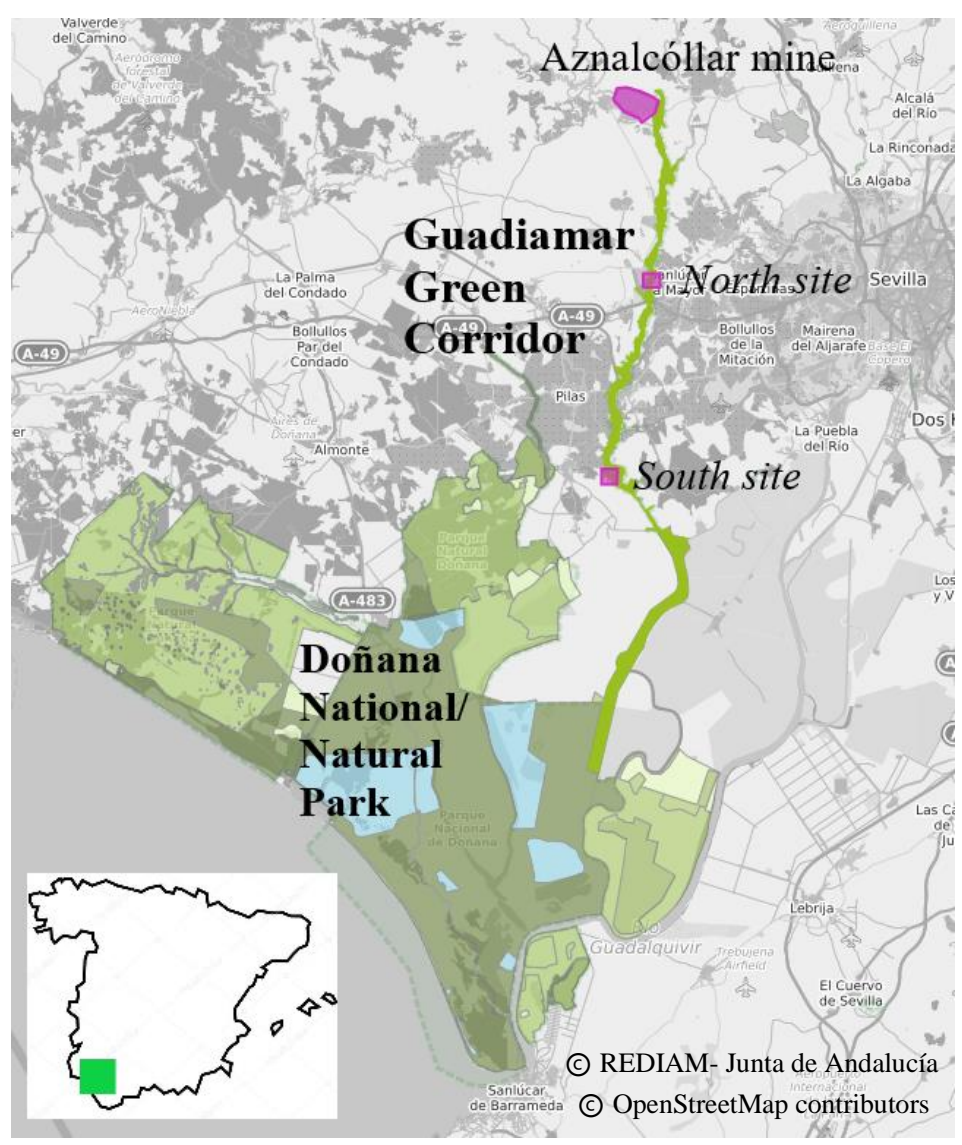


B

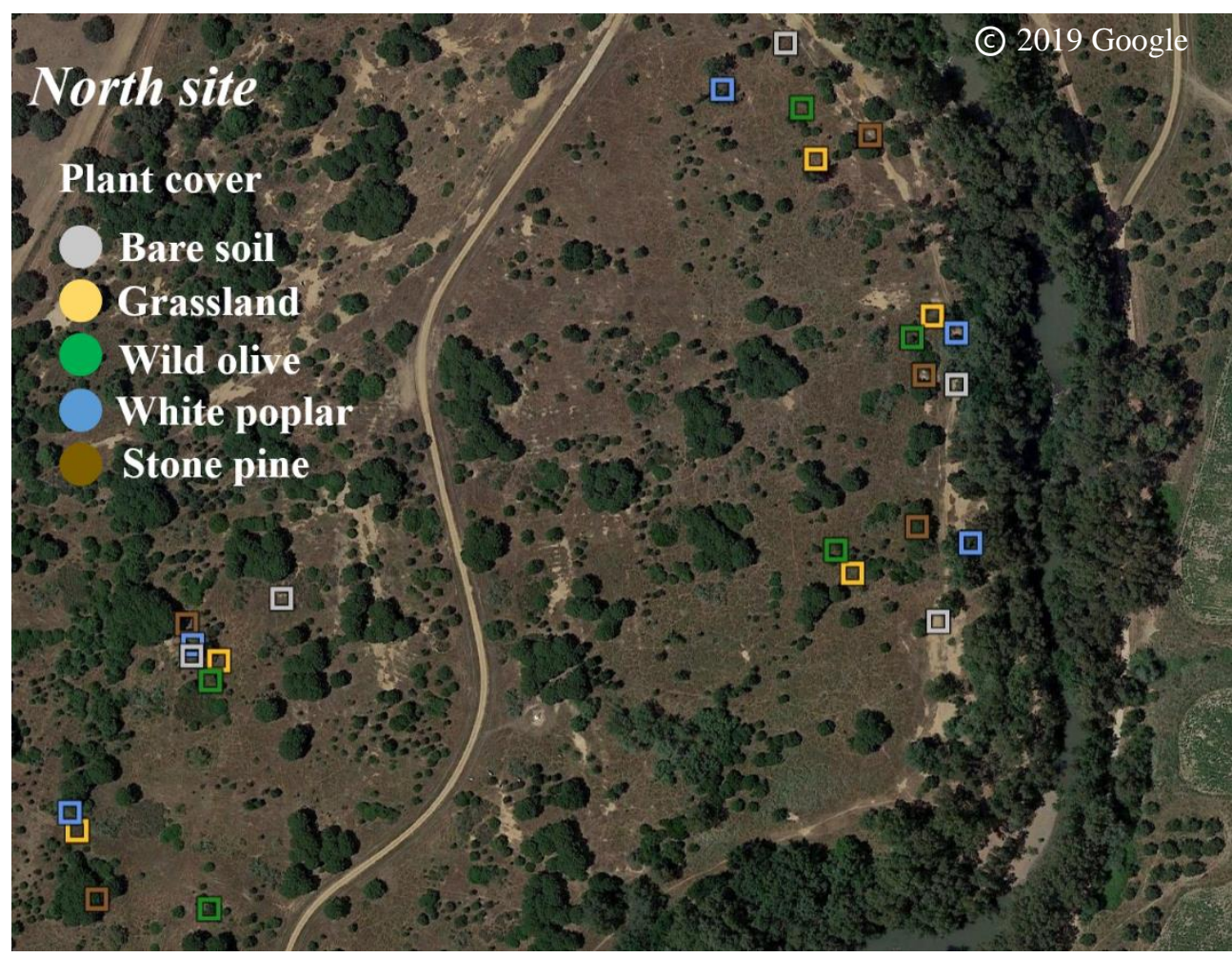

C

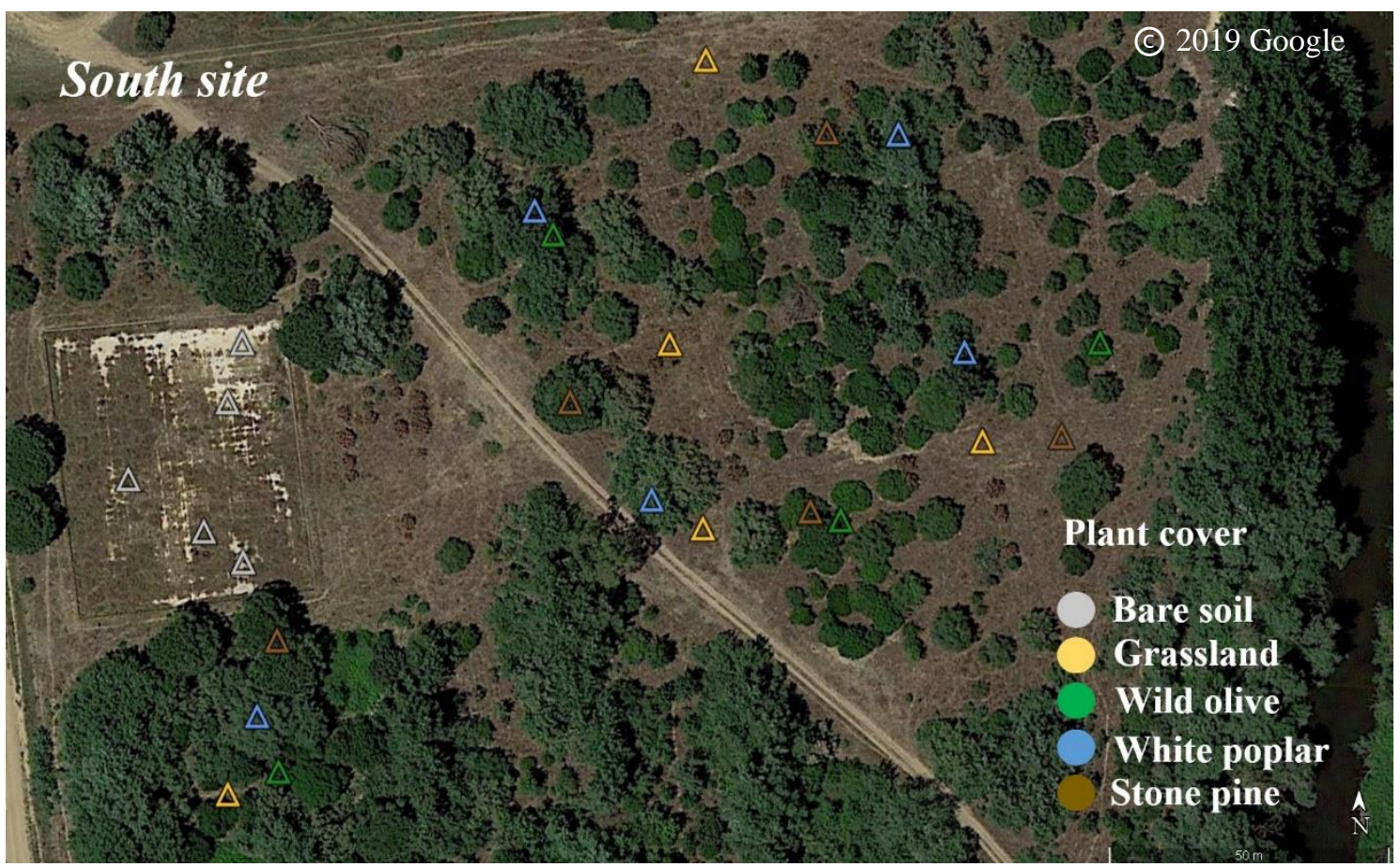

Figure S1. Location map of the study area. A) Guadiamar Green Corridor and studied sites. B) North site sampled points. C) South site sampled points. Map images from Junta de Andalucía (Consejería de Agricultura, Ganadería, Pesca y Desarrollo Sostenible), OpenStreetMap ${ }^{\circledR}$ (https://www.openstreetmap.org/copyright) and Google Earth, version 7.3.2.5776 (earth.google.com/web/). 
Table S1. Tree height and crown projection of tree species specimens.

\begin{tabular}{|c|c|c|c|c|}
\hline \multirow[b]{2}{*}{ Tree species } & \multicolumn{2}{|c|}{ Height $(\mathrm{m})$} & \multicolumn{2}{|c|}{ Crown projection $\left(\mathrm{m}^{2}\right)$} \\
\hline & North & South & North & South \\
\hline \multirow[t]{5}{*}{ Olea europaea } & 3.3 & 4.1 & 8.8 & 11.8 \\
\hline & 3.5 & 4.2 & 9.7 & 20.2 \\
\hline & 3.5 & 5.8 & 6.6 & 26.5 \\
\hline & 3.7 & 6.2 & 18.4 & 39.9 \\
\hline & 3.9 & 6.8 & 5.7 & 59.8 \\
\hline \multirow[t]{5}{*}{ Populus alba } & 8.9 & 8.0 & 45.5 & 25.1 \\
\hline & 10.7 & 9.2 & 84.9 & 34.2 \\
\hline & 11.7 & 9.6 & 63.5 & 30.8 \\
\hline & 13.9 & 10.0 & 53.6 & 102.5 \\
\hline & 17.7 & 10.8 & 102.9 & 104.0 \\
\hline \multirow[t]{5}{*}{ Pinus pinea } & 8.1 & 7.6 & 27.1 & 32.2 \\
\hline & 8.3 & 7.8 & 35.2 & 22.2 \\
\hline & 8.7 & 8.9 & 52.0 & 64.3 \\
\hline & 9.5 & 9.4 & 44.8 & 86.3 \\
\hline & 9.5 & 9.8 & 51.7 & 110.3 \\
\hline
\end{tabular}


Table S2. Two-way analysis of variance (ANOVA) statistic F with effects of Site (North and South) $(d f=1)$, Plant cover (Grassland, Olea europaea, Populus alba and Pinus pinea $)(d f=3)$ and their interaction $(d f=3)$ on soil properties $(\mathrm{n}=40)$. Asterisks indicate the significance level $(* P \leq 0.05 ; * * P \leq 0.01 ; * * * P \leq 0.001)$. $\delta$ : Non-parametric Schneirer-Ray-Hare test and H statistic; $¥$ : Box-cox transformation; $\alpha$ : VarIdent function for homocedasticity. orgC: organic carbon; DH: Dehydrogenase activity; BR: Basal respiration.

\begin{tabular}{|c|c|c|c|c|}
\hline \multirow{2}{*}{$\begin{array}{l}\text { Soil } \\
\text { properties }\end{array}$} & \multicolumn{4}{|l|}{$\mathrm{F}$} \\
\hline & $\begin{array}{l}\text { Plant } \\
\text { cover }\end{array}$ & Site & Interaction & \\
\hline $\mathrm{pH}$ & 0.26 & $296 * * *$ & 2.19 & $\delta$ \\
\hline $\mathrm{N}(\%)$ & $3.80 *$ & 1.00 & 0.35 & \\
\hline $\operatorname{orgC}(\%)$ & $6.00 * *$ & 0.12 & 0.28 & \\
\hline $\mathrm{C}: \mathrm{N}$ & $16.5 * * *$ & 4.06* & 2.62 & $\delta$ \\
\hline $\mathrm{P}\left(\mathrm{mg} \mathrm{kg}^{-1}\right)$ & 3.18 & $20.1 * * *$ & 3.05 & \\
\hline $\mathrm{Ca}\left(\mathrm{mg} \mathrm{kg}^{-1}\right)$ & $6.25 * *$ & $1000 * * *$ & 1.60 & $¥$ \\
\hline $\mathrm{K}\left(\mathrm{mg} \mathrm{kg}^{-1}\right)$ & 1.00 & 3.82 & 0.83 & \\
\hline $\mathrm{S}\left(\mathrm{mg} \mathrm{kg}^{-1}\right)$ & 0.36 & $52.9 * * *$ & 2.01 & $¥ \alpha$ \\
\hline DH $\left(\mu \mathrm{g}\right.$ INTF $\left.g^{-1} h^{-1}\right)$ & 2.87 & $12.4 * *$ & 0.36 & \\
\hline $\mathrm{BR}\left(\mu \mathrm{g} \mathrm{CO} \mathrm{CO}_{2}-\mathrm{g}^{-1} \mathrm{~h}^{-1}\right)$ & 1.03 & 4.99 & 0.16 & \\
\hline Fine sand $(\%)$ & 0.60 & $5.41 *$ & 0.15 & \\
\hline Coarse sand (\%) & 0.55 & $33.16 * * *$ & 0.50 & \\
\hline Silt (\%) & 1.02 & $26.00 * * *$ & 0.69 & \\
\hline Clay (\%) & 0.26 & $105.18 * * *$ & 1.13 & \\
\hline
\end{tabular}


Table S3. Two-way analysis of variance (ANOVA) statistic F with effects of Site (North and South) $(d f=1)$, Plant cover (Grassland, Olea europaea, Populus alba and Pinus pinea) $(d f=3)$ and their interaction $(d f=3)$ on soil trace elements $(\mathrm{n}=40)$.

Asterisks indicate the significance level $(* P \leq 0.05 ; * * P \leq 0.01 ; * * * P \leq 0.001)$. $¥$ : Box-cox transformation; $\alpha$ : VarIdent function for homocedasticity.

\begin{tabular}{lllll}
\hline $\begin{array}{l}\text { Soil } \\
\text { trace } \\
\text { elements }\end{array}$ & \begin{tabular}{l}
$\mathrm{F}$ \\
\cline { 2 - 5 } \\
clant \\
cover
\end{tabular} & Site & Interaction & \\
\hline $\mathrm{As}$ & 0.39 & $\mathbf{9 8 . 8 9} * * *$ & 0.89 & $¥ \alpha$ \\
$\mathrm{Cr}$ & 0.82 & $\mathbf{7 . 4 6}^{*}$ & 1.06 & \\
$\mathrm{Cu}$ & 0.95 & $\mathbf{2 7 5} * * *$ & 0.78 & \\
$\mathrm{Fe}$ & 0.34 & $\mathbf{1 5 9} * * *$ & 0.30 & $¥$ \\
$\mathrm{Mn}$ & 1.45 & $\mathbf{6 1 . 9} * * *$ & 1.53 & \\
$\mathrm{~Pb}$ & 0.30 & $\mathbf{8 5 . 8} * * *$ & 0.83 & $¥ \alpha$ \\
$\mathrm{Rb}$ & 1.43 & 0.60 & 0.96 & \\
$\mathrm{Sr}$ & $\mathbf{3 . 0 8} *$ & $\mathbf{1 3 . 0 5 * *}$ & 1.61 & \\
$\mathrm{Ti}$ & 1.12 & $\mathbf{4 7 . 6 3} * * *$ & 0.98 & \\
$\mathrm{~V}$ & 1.51 & $\mathbf{4 7 . 5 1} * * *$ & 1.43 & \\
$\mathrm{Zn}$ & 1.15 & 0.67 & 0.38 & \\
$\mathrm{Zr}$ & $\mathbf{3 . 3 7} *$ & $\mathbf{4 . 4 9 *}$ & 0.07 & \\
\hline
\end{tabular}




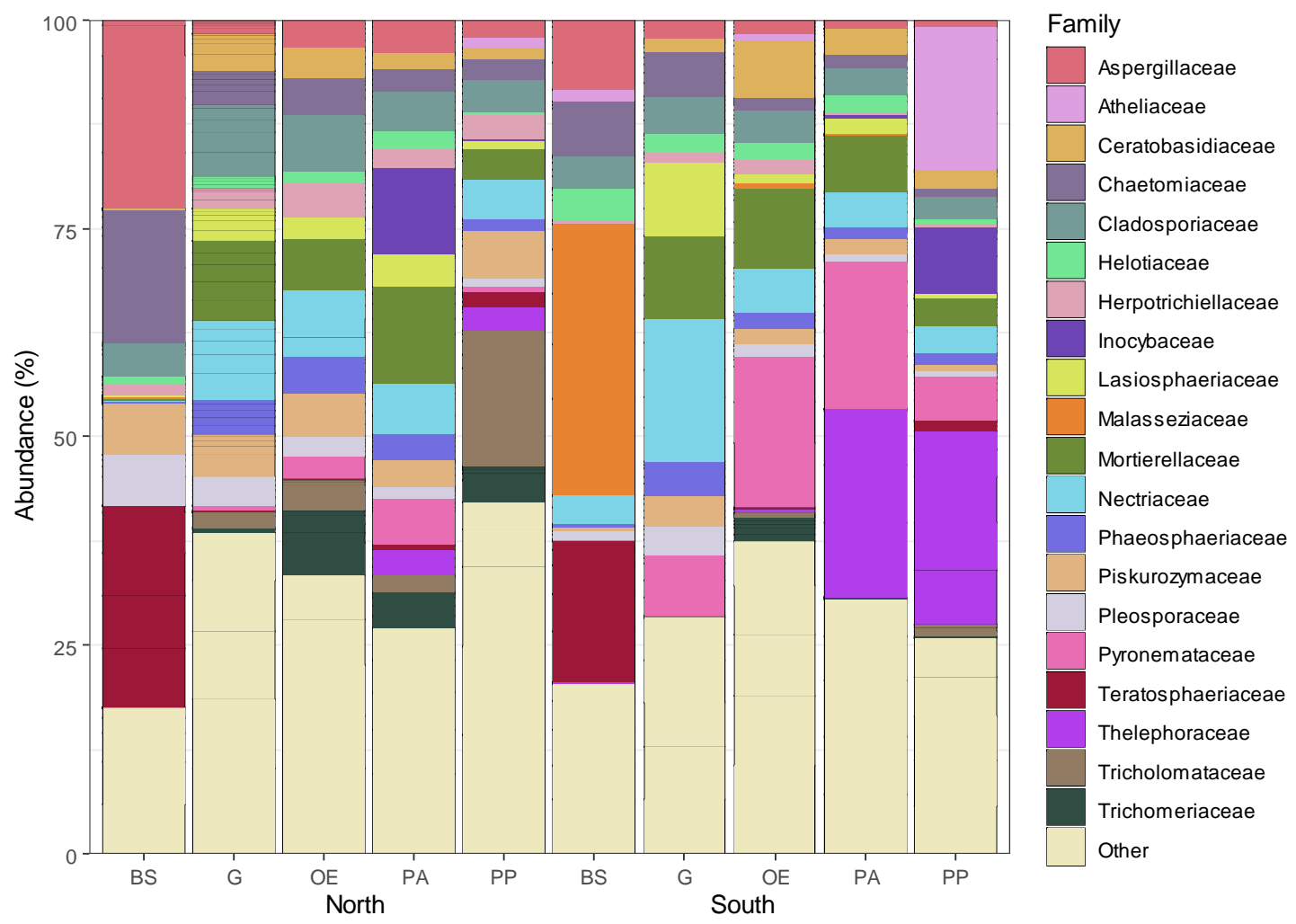

Figure S2. Relative abundance of top 20 most abundant fungal families in the 10 habitat types according to plant cover (BS = Bare soil, $\mathrm{G}=$ Grassland, $\mathrm{OE}=$ Olea europaea, $\mathrm{PA}=$ Populus alba, $\mathrm{PP}=$ Pinus pinea) and site (North, South) factors . 
Table S4. Indicator species analyses. A) Number of indicator OTUs associated to the plant cover and site factors. B) Indicator fungal species found in South site bare soils.

A

\begin{tabular}{lll}
\hline & \multicolumn{2}{l}{ Number of OTUs } \\
\cline { 2 - 3 } Plant cover & North & South \\
\hline Bare soil & 96 & 11 \\
Grassland & 90 & 374 \\
Olea europaea & 50 & 28 \\
Populus alba & 165 & 246 \\
Pinus pinea & 140 & 151 \\
\hline
\end{tabular}

B

Indicator species of non-

remediated bare soils in South

site

Coniochaeta fodinicola

Fodinomyces uranophilus

Malassezia globosa

Malassezia restricta

Pyrenopeziza revincta

Rachicladosporium sp.

Sarocladium kiliense 
Table S5. Number of total OTUs and percentage of $\gamma$-diversity in North and South soils, according to the plant cover factor. Shared OTUs between the two sites are indicated for each plant cover.

\begin{tabular}{lccc}
\hline \multirow{2}{*}{ Plant cover } & North & South & Shared \\
\cline { 2 - 4 } & Total (\%) & Total (\%) & Total (\%) \\
\hline Bare soil & $926(14.7)$ & $168(3.0)$ & $87(8.6)$ \\
Grassland & $2603(41.3)$ & $2735(48.2)$ & $944(21.5)$ \\
Olea europaea & $1953(31.0)$ & $1845(32.5)$ & $630(19.9)$ \\
Populus alba & $3021(47.9)$ & $2919(51.5)$ & $1251(26.7)$ \\
Pinus pinea & $2886(45.8)$ & $2850(50.3)$ & $1063(22.7)$ \\
\hline$\gamma$-diversity & $6301(100.0)$ & $5669(100.0)$ & \\
\hline
\end{tabular}




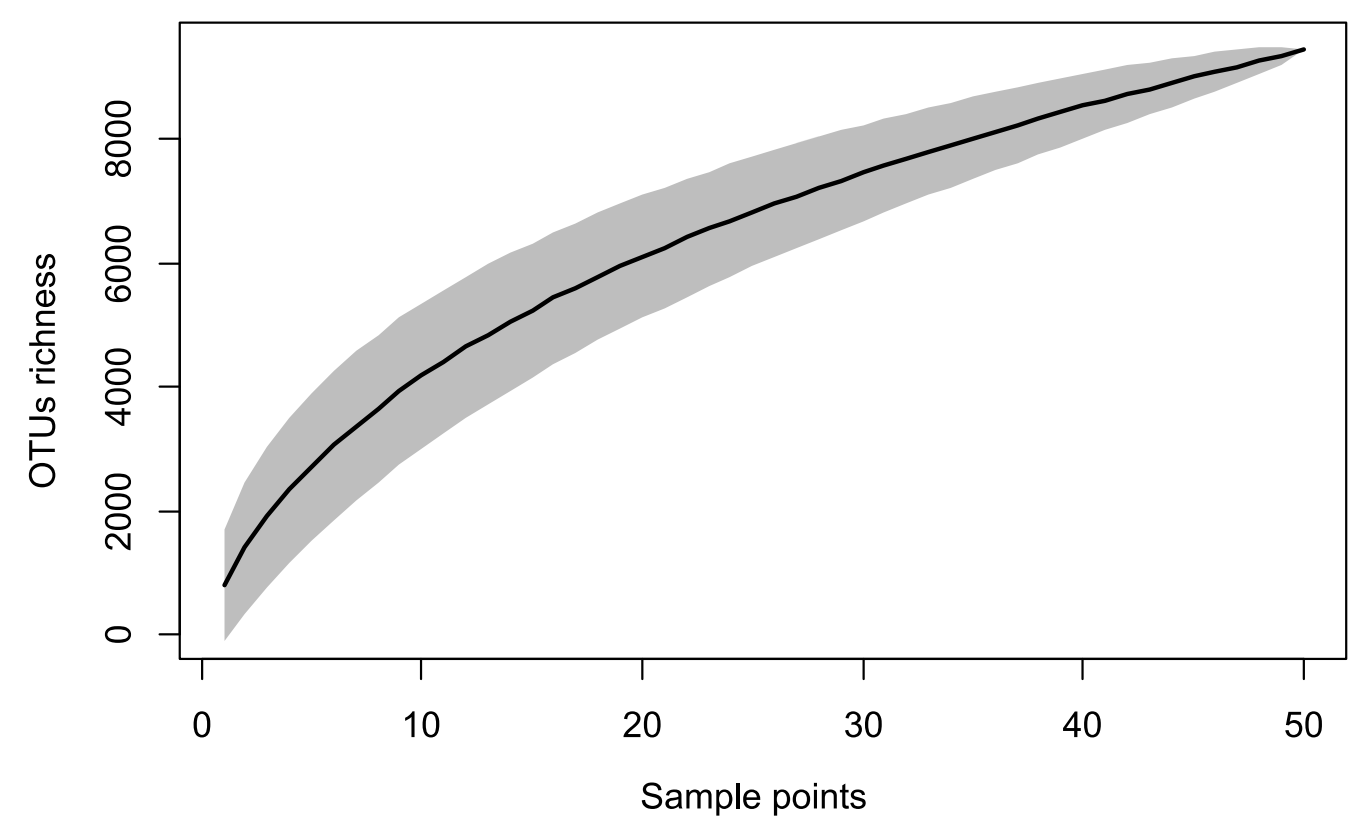

B

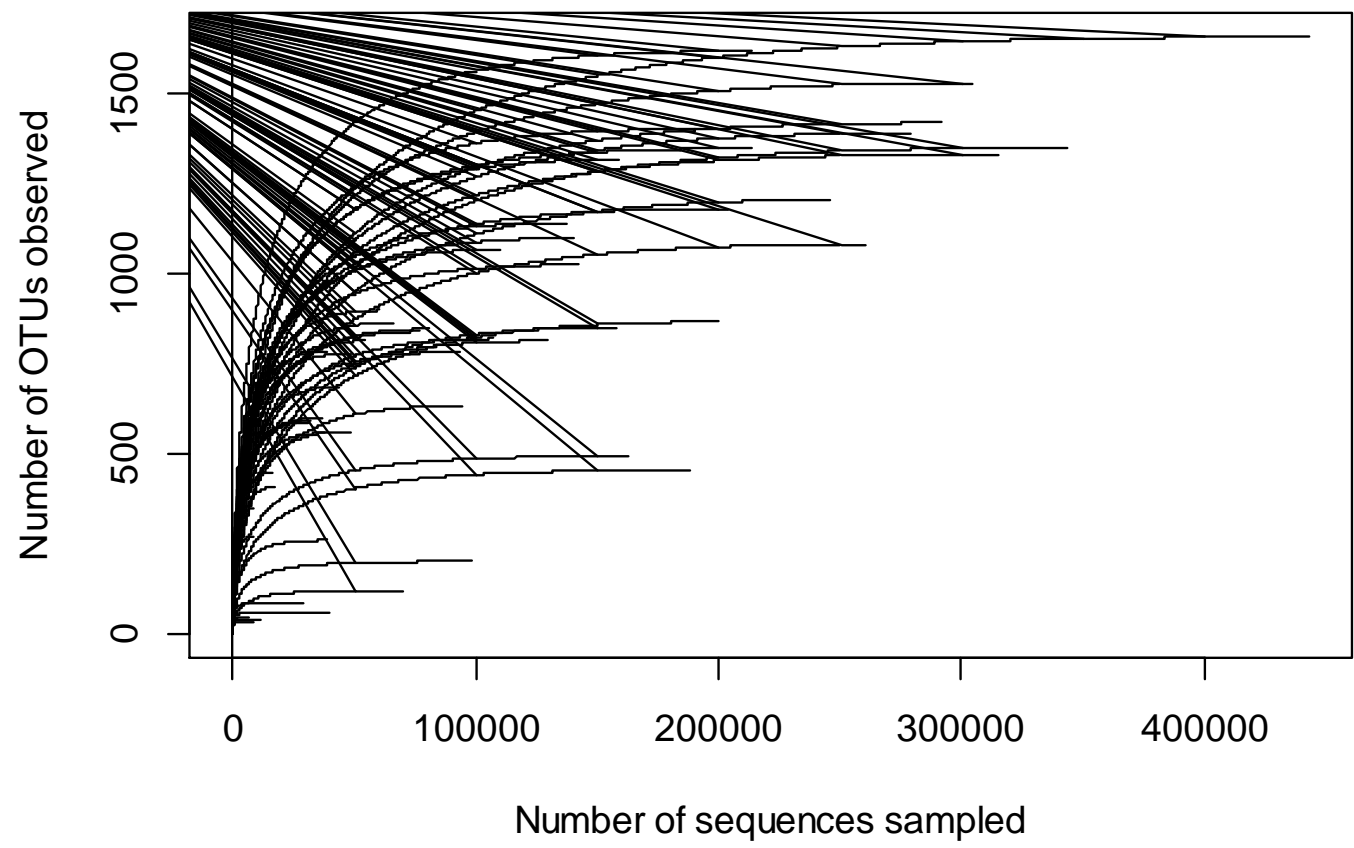

Figure S3. A) Species accumulation curve with total species richness in all sample points $(n=50)$. Confidence interval $(0.95)$ in grey. B) Sampling effort curves for the fungal community in the 50 soils sampled. 


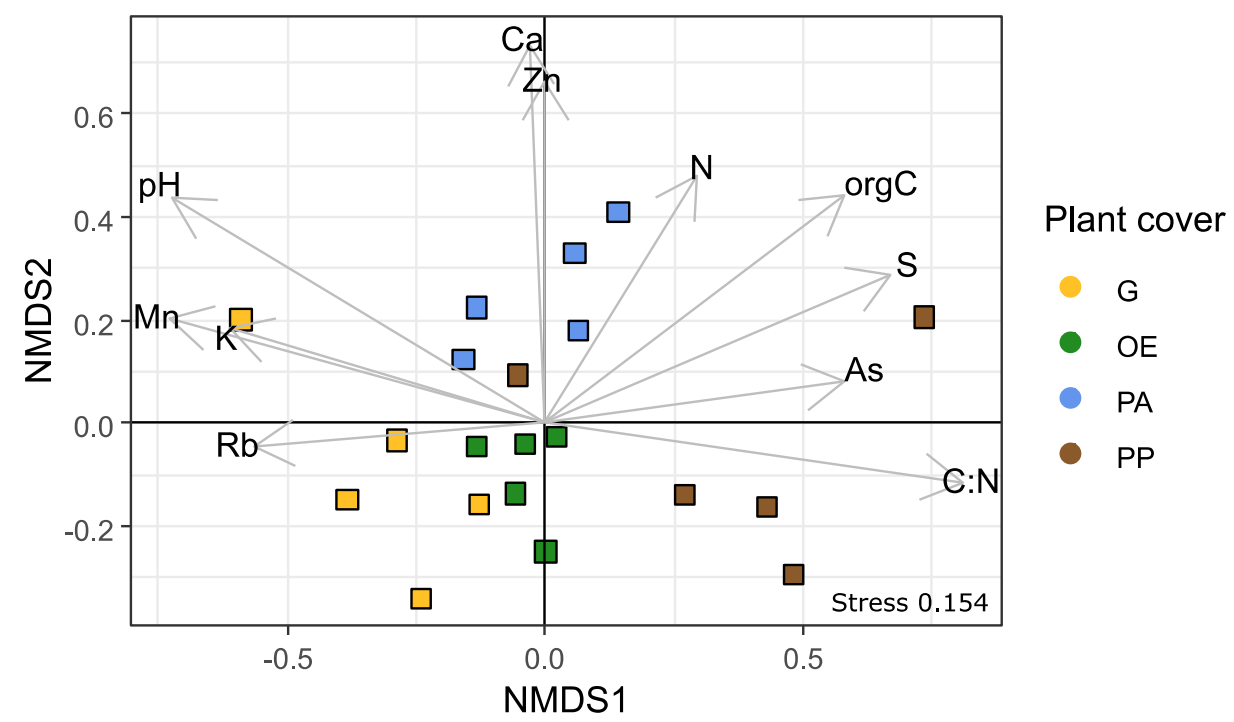

B

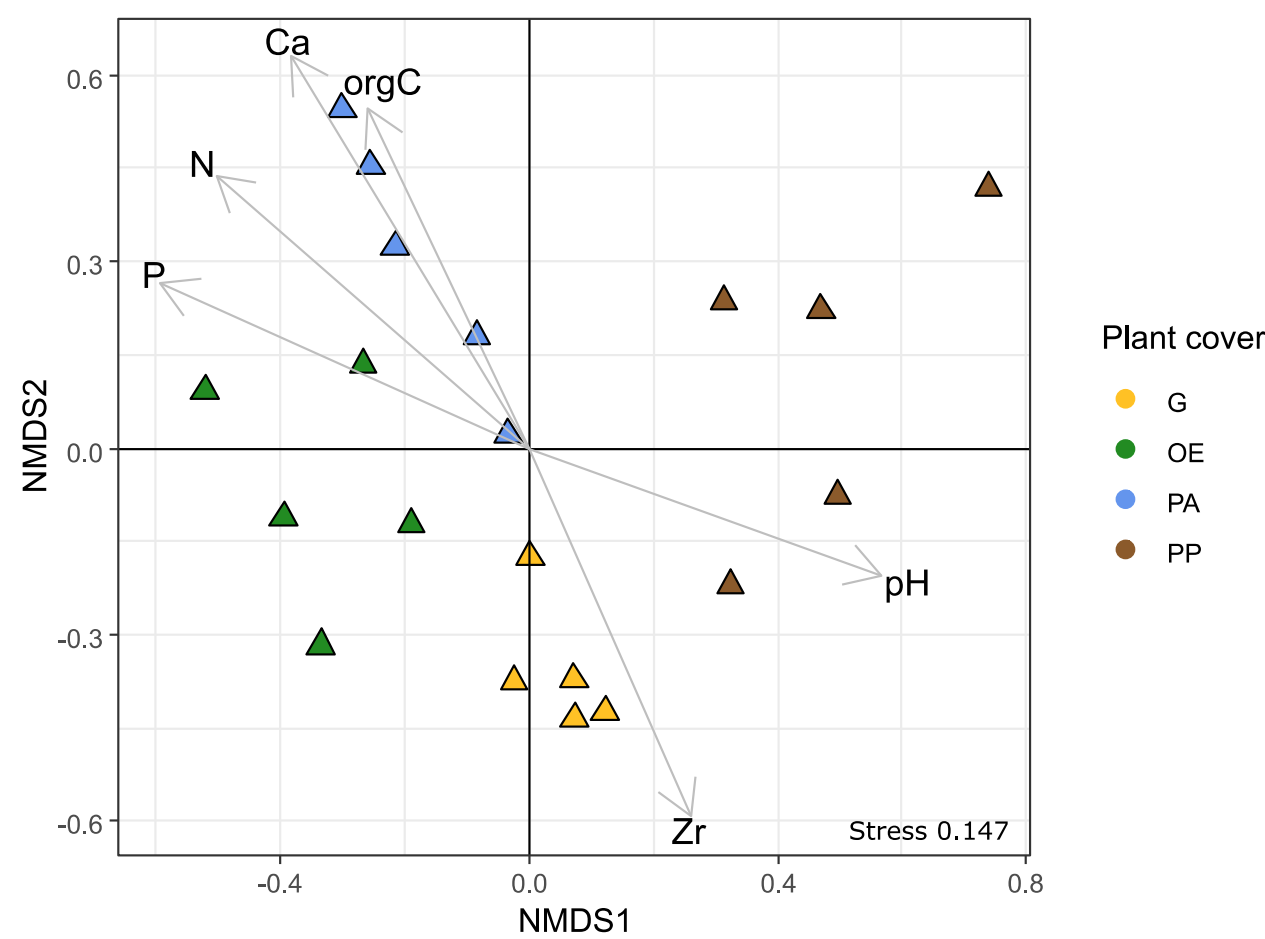

Figure S4. Non-metric multidimensional scaling (NMDS) ordination plot of fungal communities according to plant cover factor. A) North site. B) South site. Symbols according to site ( $\mathrm{N}=$ North (square) and $\mathrm{S}=$ South (triangle)) and plant cover $(\mathrm{G}=$ Grassland, $\mathrm{OE}=$ Olea europaea, $\mathrm{PA}=$ Populus alba, $\mathrm{PP}=$ Pinus pinea $)$. Significant $(P$ $<0.05)$ soil properties are presented as arrows. 
Table S6. Summary of fungal Operational Taxonomic Units (OTUs) and Reads classified according to their functional guilds from FunGUILD database.

\begin{tabular}{lllll}
\hline & OTUs & & Reads & \\
\cline { 2 - 5 } Guilds & Number & Percentage & Number & Percentage \\
\hline Saprotroph & 874 & 68.12 & 729522 & 37.45 \\
Plant pathogen & 175 & 13.64 & 136101 & 6.99 \\
Ectomycorrhizal & 119 & 9.28 & 1038103 & 53.29 \\
Animal Pathogen & 34 & 2.65 & 14626 & 0.75 \\
Fungal Parasite & 18 & 1.40 & 1455 & 0.07 \\
Arbuscular Mycorrhizal & 17 & 1.33 & 2993 & 0.15 \\
Lichenized & 17 & 1.33 & 3205 & 0.16 \\
Endophyte & 12 & 0.94 & 9345 & 0.48 \\
Orchid Mycorrhizal & 10 & 0.78 & 11840 & 0.61 \\
Ericoid Mycorrhizal & 4 & 0.31 & 645 & 0.03 \\
Epiphyte & 2 & 0.16 & 25 & 0.00 \\
Lichen Parasite & 1 & 0.08 & 61 & 0.00 \\
\hline TOTAL GUILDS & 1283 & 100 & 1947921 & 100 \\
\hline (Undefined) & 7125 & & & \\
(Possible) & 616 & & & \\
(Multiple guilds) & 404 & & & \\
\hline TOTAL & & & & \\
\hline & & & & \\
\hline
\end{tabular}




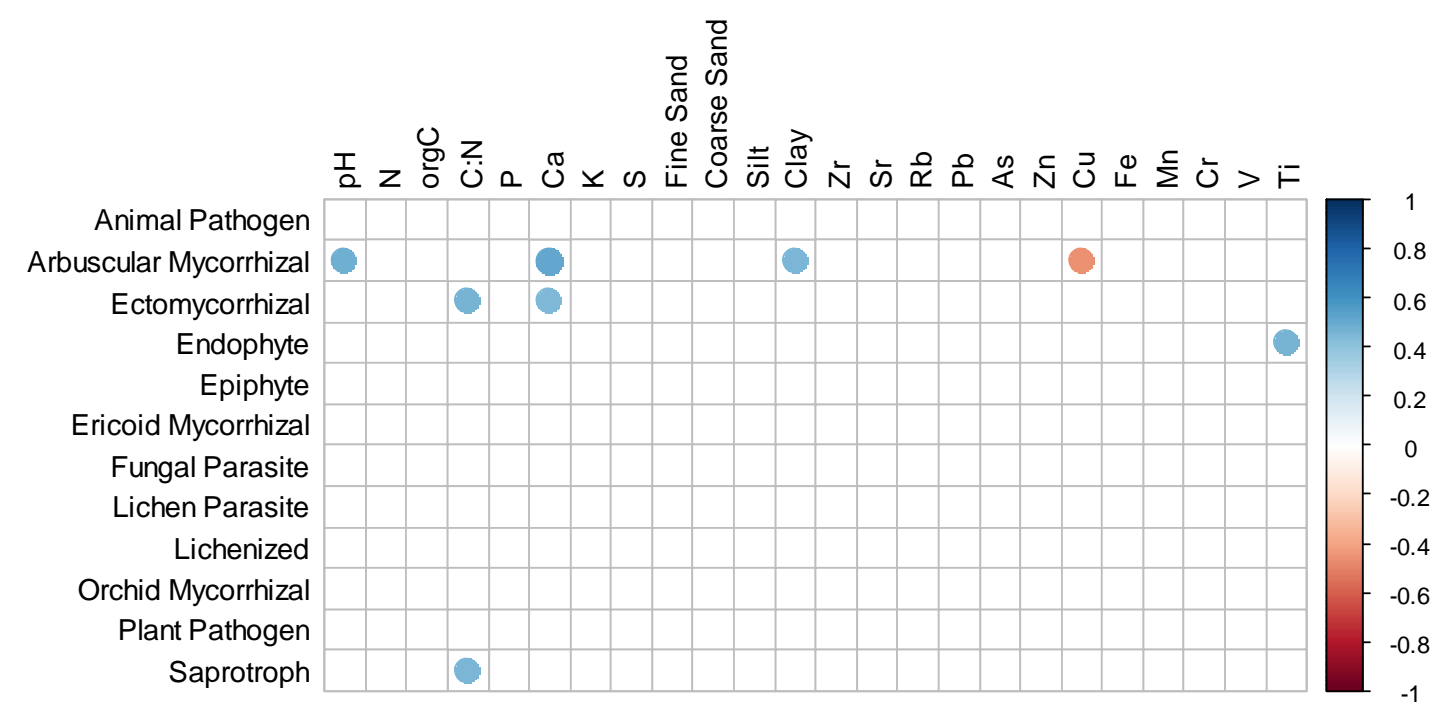

Figure S5. Pearson's correlation coefficient between functional guilds abundance and soil abiotic variables excluding bare soil $(n=40)$. Circles indicate significant differences $(P<0.05)$; blue and red colours indicate positive and negative correlation, respectively. 


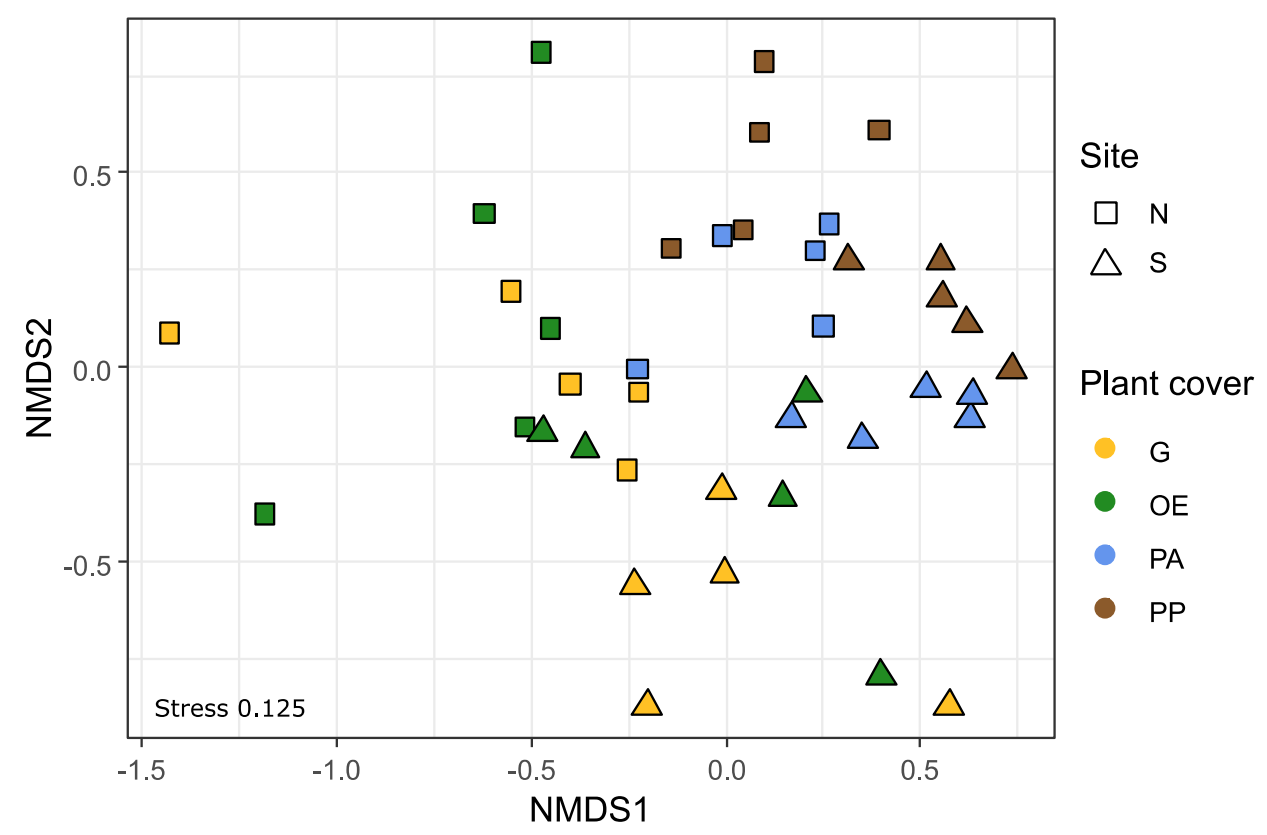

Figure S6. Non-metric multidimensional scaling (NMDS) ordination plot of ectomycorrhizal fungal communities according to plant cover and site factors. Symbols according to site $(\mathrm{N}=$ North (square) and $\mathrm{S}=$ South (triangle) ) and plant cover $(\mathrm{G}=$ Grassland, $\mathrm{OE}=$ Olea europaea, $\mathrm{PA}=$ Populus alba, $\mathrm{PP}=$ Pinus pinea $)$. 